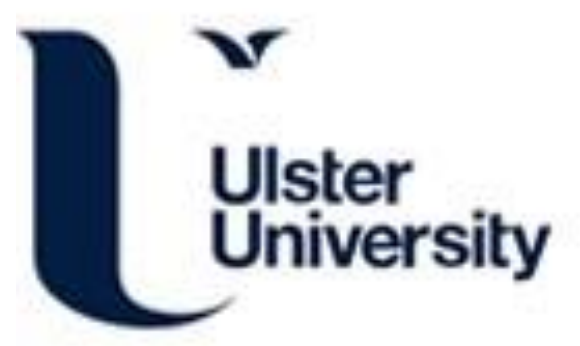

\title{
Diabetes in people with intellectual disabilities: A systematic review of the literature
}

MacRea, S., Brown, M., Karatzias, T., Taggart, L., Truesdale-Kennedy, M., Walley, R., Sierka, A., Northway, R., Carey, M., \& Davies, M. (2015). Diabetes in people with intellectual disabilities: A systematic review of the literature. Research in Developmental Disabilities, 47, 352-374. https://doi.org/10.1016/j.ridd.2015.10.003

Link to publication record in Ulster University Research Portal

\section{Published in:}

Research in Developmental Disabilities

Publication Status:

Published (in print/issue): 01/12/2015

DOI:

10.1016/j.ridd.2015.10.003

\section{Document Version}

Author Accepted version

\section{General rights}

Copyright for the publications made accessible via Ulster University's Research Portal is retained by the author(s) and / or other copyright owners and it is a condition of accessing these publications that users recognise and abide by the legal requirements associated with these rights.

\section{Take down policy}

The Research Portal is Ulster University's institutional repository that provides access to Ulster's research outputs. Every effort has been made to ensure that content in the Research Portal does not infringe any person's rights, or applicable UK laws. If you discover content in the Research Portal that you believe breaches copyright or violates any law, please contact pure-support@ulster.ac.uk. 


\section{Accepted Manuscript}

Title: Diabetes in People $\times$ with Intellectual Disabilities: A Systematic Review of the Literature

Author: Siobhan MacRae PGDip Michael Brown PhD

Thanos Karatzias PhD Laurence Taggart PhD Maria

Truesdale-Kennedy PhD Robert Walley D.Psychol Anna

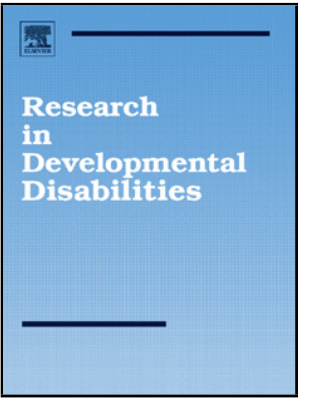

Sierka BSc Ruth Northway PhD Marian Carey PhD Melanie

Davies MD

PII:

S0891-4222(15)00174-2

DOI:

http://dx.doi.org/doi:10.1016/j.ridd.2015.10.003

Reference:

RIDD 2716

To appear in: $\quad$ RIDD

Received date: $\quad$ 24-11-2014

Revised date: $\quad 21-8-2015$

Accepted date: $\quad$ 7-10-2015

Please cite this article as: MacRae, S., Brown, M., Karatzias, T., Taggart, L., TruesdaleKennedy, M., Walley, R., Sierka, A., Northway, R., Carey, M., and Davies, M.,Diabetes in People<ce:hsp $\mathrm{sp}=\ddot{0} .25 \ddot{/}>$ times $<$ ce:hsp $\mathrm{sp}=\ddot{0} .25 \ddot{\%}>$ with Intellectual Disabilities: A Systematic Review of the Literature, Research in Developmental Disabilities (2015), http://dx.doi.org/10.1016/j.ridd.2015.10.003

This is a PDF file of an unedited manuscript that has been accepted for publication. As a service to our customers we are providing this early version of the manuscript. The manuscript will undergo copyediting, typesetting, and review of the resulting proof before it is published in its final form. Please note that during the production process errors may be discovered which could affect the content, and all legal disclaimers that apply to the journal pertain. 


\section{$\underline{\text { Title }}$}

Diabetes in People with Intellectual Disabilities: A Systematic Review of the Literature

\section{Abbreviated Title}

Diabetes in People with Intellectual Disabilities

\section{Authors}

MacRae, Siobhan, PGDip ${ }^{1}$

Brown, Michael, $\mathrm{PhD}^{1,2}$

Karatzias, Thanos, $\mathrm{PhD}^{1,3}$

Taggart, Laurence, $\mathrm{PhD}^{4}$

Truesdale-Kennedy, Maria, $\mathrm{PhD}^{4}$

Walley, Robert, D.Psychol, ${ }^{1,5}$

Sierka, Anna, BSc ${ }^{1}$

Northway, Ruth, $\mathrm{PhD}^{6}$

Carey, Marian, $\mathrm{PhD}^{7}$

Davies, Melanie, MD ${ }^{7,8}$

\section{Affiliations}

1 Edinburgh Napier University, Faculty of Health, Life and Social Sciences, UK 2 NHS Lothian Specialist Learning Disability Services, UK

${ }^{3}$ NHS Lothian, Rivers Centre for Traumatic Stress, UK

${ }^{4}$ University of Ulster, Institute of Nursing and Health Research, UK

${ }^{5} \mathrm{NHS}$ Lothian East and Midlothian Community Learning Disability Teams, UK ${ }^{6}$ University of South Wales, Faculty of Life Sciences and Education, UK ${ }^{7}$ Leicester Diabetes Centre, University Hospitals of Leicester, UK

${ }^{8}$ University of Leicester, Diabetes Research Centre, UK

Address for Correspondence and reprint requests

Professor Michael Brown

Edinburgh Napier University

Sighthill Campus

Sighthill Court

Edinburgh EH11 4BN

Scotland, UK

Tel. (+44)(0)1314555679

Email. M.brown@napier.ac.uk 
Title: Diabetes in People with Intellectual Disabilities:

A Systematic Review of the Literature

\begin{abstract}
OBJECTIVE - To present an analysis of the evidence related to the prevalence of diabetes in people with intellectual disabilities (ID), their experiences of their condition and treatment and those of their carers.

MATERIALS AND METHODS - A systematic literature review was conducted. A total of 22 studies exploring diabetes prevalence and 5 exploring views and experiences of diabetes in people with ID were identified and included. A narrative synthesis approach was utilised to amalgamate data extracted from the included studies regarding some 49, 046 participants with ID and diabetes and 31 care professionals and family members across Europe, North America, New Zealand, Australia, China and Hong Kong.
\end{abstract}

RESULTS - Prevalence rates of diabetes in people with ID were highly varied, ranging from $0.4 \%$ to $25 \%$. 7 studies reported significantly higher rates of diabetes in people with ID than the general population. People with ID reported a basic understanding of diabetes and wanted to know more. Carers reported that they lack diabetes knowledge and do not routinely encourage diabetes self-management skills. Several studies neglected to report vital demographic information such as participants' level of ID (13 studies) and diabetes type (16 studies) and the quality of included prevalence studies was variable.

CONCLUSIONS - Further research in this field is required, notably prevalence studies which control for participant demographics and personal situations to obtain more accurate diabetes prevalence rates in this population group. People with ID and diabetes should be encouraged to participate in future research and we recommend exploring the feasibility of adapting current mainstream diabetes management programmes for these individuals.

Key words: intellectual disabilities; learning disabilities; developmental disabilities; diabetes; prevalence; views; opinions; diabetes management; systematic review 


\section{INTRODUCTION}

The term intellectual disabilities (ID) is characterised by significant limitations in intellectual functioning and adaptive behaviours originating before age 18. People with ID typically display an IQ below 70 and limited conceptual, social, practical and adaptive skills (1). A range of alternative terms are used internationally, such as learning disabilities (LD), developmental disabilities (DD) and, less commonly, mental retardation (MD), which essentially label the same condition. ID remains the most widespread, universally recognised term and will be utilised throughout this paper.

People with ID constitute $1-2.5 \%$ of the population in the Western world (2). Studies from England (3) and Australia (4) report similar prevalence rates of $2 \%$ and $2-3 \%$ respectively. It has been previously recognised that people with ID experience poorer health compared with the general population (5) in addition to a higher prevalence of physical health conditions and significant barriers to adequate health care (6). There is a paucity of research specifically targeting diabetes and people with ID, yet it is apparent that it is an area requiring further attention considering evidence suggesting people with ID are more likely to experience the major diabetes risk factors - poor nutrition; high fat, sugar and salt intake; high blood pressure; a sedentary lifestyle with limited physical activity and associated obesity (7) (8-13). The worldwide prevalence of diabetes is rapidly increasing, as is the number of people dying as a consequence of diabetes-related complications (14). Furthermore, a 14\% increase in the number of people with ID by 2021 is predicted (15) with life expectancy advancing (16). Diabetes is, therefore, impacting on the lives of people globally and evidence points to increasing complications and risk. People with ID are more likely to experience the major risk factors associated with diabetes and are living longer. As a consequence, appropriate access to healthcare and additional resources is required yet research focusing on the distinct needs of this population remains limited.

This paper presents findings from a systematic review of the current research evidence related to diabetes and people with ID. The review systematically evaluates data obtained from a total of 27 studies. It is envisaged that examining the available literature will identify gaps in evidence which can be used to inform further research and clinical practice in this field. 


\subsection{Systematic review questions}

1. What is the prevalence of diabetes amongst people with ID?

2. What are the views of people with ID on managing their diabetes and the service they receive?

3. What are the views of carers of people with ID and diabetes regarding diabetes management and the current service provision?

\section{MATERIALS AND METHODS}

\subsection{Search strategy}

The primary literature search was carried out between October and November 2013 by the lead researcher. A comprehensive computerised search of the literature was conducted using 14 English language databases: AMED, CINAHL, MEDLINE, PsycINFO, ASSIA, ZETOX, PubMed, Psychology and Behavioural Sciences Collection, Sociological abstracts, Expanded Academic ASAP, Science Direct, Wiley Online Library, Web of Knowledge and Ingenta Connect. A search strategy for each database was developed using combinations of the following key words: intellectual disab* or learning disab* or developmental disab* or mental retard* and diab* to represent ID, LD, DD, mental retardation and diabetes. Citations from relevant research articles were followed up for potential research studies. After publication by McVilly et al., in Australia (50) of their systematic review exploring diabetes in people with intellectual and developmental disabilities (IDD), the references were examined and a further 8 studies identified.

\subsection{Inclusion and exclusion criteria}

The following inclusion and exclusion criteria were employed:

1. Type of paper: Primary data research, published in English, in peer-reviewed journals.

2. Study design: For question 1, studies employing quantitative research methods were included. For questions 2 and 3, quantitative and qualitative studies were included.

3. Population: In light of differing terminology, studies which recruited participants with either ID, LD, DD or mental retardation and diabetes were included. The universal term ID has been adopted throughout this paper. Parents, guardians, 
professional care givers and health care staff who directly support people with ID and diabetes were also included to identify their views on diabetes management. No particular participant demographics were targeted.

4. Outcome: For question 1, studies which stated a measure of the prevalence of diabetes in people with ID, providing a quantitative and / or statistical estimate, were included. For questions 2 and 3, studies that directly discussed views on diabetes knowledge, self-management and service provision from a service user and / or carer perspective were included.

\subsection{Quality assessment}

The quality of the included quantitative studies was assessed using a standardised tool, the Quality Assessment Tool for Quantitative Studies (17). The tool consists of eight components: (i) the extent to which study participants are representative of the target population, (ii) study design, (iii) control of confounding factors, (iv) blinding of outcome assessors and participants, (v) reliability and validity of the data-collection tools, (vi) the number of withdrawals and drop-outs, (vii) intervention integrity and (viii) intervention analyses. The fourth, seventh and eighth criteria were considered not applicable for the included studies as these were cross-sectional or case-control in nature and did not test the effect of an intervention. For all studies, each of the five remaining criteria were rated as "strong", "moderate" or "weak" according to standardised criteria. An overall rating of "strong" was obtained when there was no weak component, "moderate" when there was one weak component and "weak" when there were two or more weak components. In lieu of an agreed standardised tool for assessing the quality of the included qualitative studies, Hannes' (18) framework on the critical appraisal of qualitative research was used. Credibility, transferability, dependability and confirmability are deemed the core elements of quality in such studies. According to this method, credibility describes whether or not the representation of data fits the views of the participants studied and whether the findings hold true; transferability describes whether research findings are transferable to other specific settings; dependability describes whether the process of research is logical, traceable and clearly documented, particularly on the methods chosen and the decisions made by the researchers; and confirmability describes the extent to which findings are qualitatively confirmable through the analysis being grounded in the data and through examination of the audit trail. A qualitative study is of high quality if it satisfies three or more of these indications. 


\subsection{Synthesis}

A narrative synthesis approach was employed to amalgamate data extracted from the studies. Paper copies of all papers were read by the authors (SMcR, MB, TK) to aid data extraction related to the questions of the review as well as characteristics of the papers to assess their quality. Every paper was read by at least two of the research team. The characteristics of the original research were assessed using a predetermined framework and the following data were extracted: participant characteristics, aim of the study; prevalence measure, results, analysis method and limitations.

\section{RESULTS}

\subsection{Search results}

A flow diagram of data retrieved at each stage of the literature search can be seen in Figure 1. A total of 27 studies $(19-37,51-58)$ met the inclusion criteria and were included in the systematic review. 22 studies $(19-32,51-58)$ provided data on the prevalence of diabetes in people with ID, 3 (33-35) provided data on their views and experiences of having diabetes and 3 (35-37) provided data on the views and experiences of family members and professional carers who support people with ID and diabetes.

\section{FIGURE 1 ABOUT HERE}

\subsection{Quality of available evidence}

The quality of the reviewed studies is set out in Tables $1 \& 2$. All but $2(27,55)$ of the prevalence studies obtained a strong or moderate quality rating and all but 1 (37) of the experiential studies obtained a high quality rating. The main reasons for the poorer quality ratings of studies were the use of cross-sectional designs, unrepresentative samplings and limited information about participants, methodologies and analyses.

\section{TABLE 1 ABOUT HERE}

TABLE 2 ABOUT HERE

\subsection{Prevalence of diabetes in people with intellectual disabilities}

A total of 11 studies reporting diabetes prevalence rates in people with ID have been 
conducted throughout the US and Canada $(22,23,26-31,51,52,57), 8$ were conducted in Europe; 1 Europe-wide study (54), 4 in the Netherlands $(20,21,32,58)$, 3 in the UK $(19,25,55)$ and 1 in Sweden (24), 1 study was conducted in Hong Kong (53) and 1 in China (56). Table 3 summarises the demographic data, participant characteristics, aims, measurement methodology, findings and limitations obtained from the included studies in which a total of 49,011 people with ID and diabetes participated.

\section{TABLE 3 ABOUT HERE}

The largest study sample comprised of 29, 010 participants (26), while the smallest comprised of 17 participants (24). Male participants outnumbered female participants in 13 studies and for the studies which reported it, the mean age of participants was 38 years, with the lowest mean age reported as 14 years (30) and the oldest, 61 (20, 21). Where reported, the majority of participants had a mild level of ID, resided in residential settings and Down's Syndrome and cerebral palsy were the most common co-existing conditions.

The average diabetes prevalence in people with ID across all 22 studies was $8.3 \%$. Eleven studies suggested diabetes occurs more frequently in people with ID than the general population, however only 8 reported results that reached statistical significance $(20-23,28-30,32)$. Three studies suggested diabetes is less prevalent in people with ID compared to the general population $(27,52,57)$. The remaining 8 studies provided prevalence figures which ranged from $0.4 \%$ (22) to $25 \%$ (19). Three of these studies specifically sampled people with chromosomal syndromes, such as Down's Syndrome (22) and Prader-Willi Syndrome (19, 24), 2 sampled older people $(20,21)$ and 1 sampled adolescents (30). Of the studies which explored diabetes prevalence across the ID population, higher prevalence figures were more common in studies undertaken in North America and the Netherlands. Three of the Dutch studies reported similar diabetes prevalence figures of $11.2 \%(32)$ and $12.5 \%(20,21)$ in people with ID, however, the remaining Dutch study (58) reported a lower prevalence figure of $3.4 \%$. The 9 studies from the United States (US) reported considerable variance ranging from $0.4 \%$ (Goldacre) to $18.5 \%$ (29). Two studies carried out within the same US state of Kansas obtained different prevalence rates $(18.5 \%$ from Reichard and Stolzle (29) and 11.2\% from Shireman et al., (31), despite being published within a year of each other. Seven of the included studies identified certain 
characteristics associated with higher rates of diabetes in people with ID, such as having a co-morbid severe mental health issue $(26,52)$, a milder level of ID (20), a cause of ID other than Down's Syndrome $(20 ; 28)$, having Down's Syndrome and being under 30 years old (22), shopping independently for groceries (20), being at an advanced age (54) and being obese $(30,52)$.

All but one of these studies (19) made no distinction between participants $\square$ diabetes type, 14 made no distinction between participants $\square$ living arrangements, and 10 made no distinction between participants $\square$ level of ID. The majority of these studies identified prevalence rates from valid measures, such as accessing medical records and noting the frequency of medically diagnosed cases, or carrying out blood glucose level testing. However, 5 studies $(19,28,30,53,54)$ relied on self-reporting of diabetes from either the people with ID themselves, their family members or care staff without verifying blood testing or medical case file review. The analysis of the studies indicate that the precise prevalence of diabetes in people with ID remains unknown, however, the evidence suggests that the overall prevalence rate is higher than the non-ID population.

\subsection{The views of people with intellectual disabilities of diabetes management and diabetes service provision}

Of the 3 studies reporting the experiences of people with ID and diabetes, 1 was conducted in the Netherlands (33), 1 in the UK (34) and 1 in New Zealand (35). Table 4 summarises the demographic data, participant characteristics, aims, findings, methods of analysis and limitations obtained from the included studies in which 35 people with ID and diabetes participated.

\section{TABLE 4 ABOUT HERE}

The studies' samples comprised of 17 (33), 14 (35) and 4 (34) participants respectively. Female participants outnumbered male participants in 2 studies (33 \& 34) and the mean ages of participants were 52 (33), 35 (34) and 50.9 years (35). Where reported, the majority of participants had type 2 diabetes, a mild or moderate level of ID, resided in residential or community housing settings; Down's Syndrome was the most commonly reported co-existing condition.

One of the main themes identified from the Cardol study (33) is that people with ID 
and diabetes experienced a feeling of loss with regard to food intake and choices where participants described not being able to eat what they wanted. Another major theme focussed on medication and control, where participants reported being familiar with blood tests and of the need to take medication and attend medical appointments for review. Respondents viewed these appointments as more helpful when supported by family members or professional carers. Cardol et al., also identified participants not feeling unwell as a pivotal theme and their diabetes was only viewed as „serious $\square$ when insulin was required. Participants also experienced difficulty differentiating between diabetes symptoms and symptoms arising from other comorbid health conditions. A final major theme identified in this study was self-management, where respondents reported that their understanding of diabetes, motivation for selfmanagement and special occasions are related to the intention to self-manage. Furthermore, support from professionals and others can encourage self-management behaviours while health factors, mood and contextual factors can impede selfmanagement.

A theme identified by Dysch et al., (34) was participants $\square$ understanding of diabetes with respondents reporting a basic understanding of their condition, notably its cause and complications. The physical effects of diabetes was identified as an important theme, where participants could describe the physical experience of diabetes such as awareness of fluctuating blood sugar levels. A difficult relationship with diabetes was also highlighted where participants reported feeling frustrated with the restrictions and inconveniences of diabetes. This study also found that diabetes had a negative social impact as participants considered diabetes to be socially stigmatising. Another pivotal theme identified was the support participants received for managing their diabetes where all respondents reported receiving some form of support in both the treatment of diabetes and a healthy lifestyle. An additional theme that emerged was that diabetes was not the only health issue experienced by participants and this often impacted upon self-management of diabetes behaviours.

Hale et al., (35) also identified similar pivotal themes, one of which was participants' level of knowledge and understanding of diabetes, where some participants had a good understanding and most a basic understanding related to physical symptoms. Another important theme was that participants had an awareness of changes in their blood glucose level. Additionally participants displayed an understanding of the role of 
diet and physical activity and reported that staff controlled food portion sizes and limited choices. Participants' information needs was another major theme where most reported that they could not recall receiving information about diabetes when they were first diagnosed and expressed a desire to learn more about their condition. Diabetes management was highlighted with some participants reported managing their diabetes with minimal support, many reported receiving routine blood tests and all reported receiving a minimum annual health check. Support was another identified theme where most respondents cited staff and health advisors in their residential service as the main points of support, with 5 of the 14 participants having an individual diabetes management plan. Participants were also asked how they felt about having diabetes and provided a range of views; some were unconcerned, however, others expressed anger and frustration at the limitations they experienced physically and socially.

There was over-representation of females across the studies as well as individuals with mild to moderate ID as opposed to more severe and profound levels. Two of the studies utilised convenience sampling $(33,34)$ and with only 4 participants, Dysch et al., (34) drew on a small sample. No distinctions were made between level of ID in 2 studies $(34,35)$ and no distinction between living arrangements in 1 (35). All 3 studies utilised valid qualitative analysis techniques, with Hale et al., (35) using the general inductive approach (38), Dysch et al., (34) using interpretative phenomenological analysis and Cardol et al., (33) using Leventhal's common sense model (39) and thematic analysis and grounding theory (40). The lead researcher's interpretations were further validated in all 3 studies as transcripts were read several times, independently considered by more than one researcher and discussed so that a general consensus on the main themes was reached. Only 1 study (33) reported utilising pictographs to enhance understanding and clarification during the interview stage.

The analysis of the findings suggest that people with ID have a basic understanding of their diabetes and management. Participants cited family members and professional care staff as their main source of advice, support and encouragement in managing diabetes, however, opportunities to learn new self-management skills are not routinely offered. For some, comorbid health conditions impeded their recognition of diabetes symptoms and management and respondents would like to know more 
about diabetes.

\subsection{The views of family carers and professional care staff on diabetes management and diabetes service provision}

The study by Hale et al., (35) reviewed in section 3.4 reported the views from professional care staff and so will be reviewed again here. An additional 2 studies reported the experiences of individuals who support people with ID and diabetes, 1 in the Netherlands (36) and 1 in Australia (37). Two of these studies collected the experiences and views from professional care staff $(35,36)$ and one obtained these views from parent carers (37).

Table 5 summarises the demographic data, participant characteristics, aims, findings, methods of analysis and limitations obtained from the included studies in which 31 professional caregivers and family carers of people with ID and diabetes participated.

\section{TABLE 5 ABOUT HERE}

The studies' samples comprised of 4 (37), 13 (36) and 14 participants (35) respectively. Female participants outnumbered male participants in 1 study (36).

The main findings that emerged from Hillege et al., (37) study centred on themes of independence. In terms of independence and the family member with ID, parents felt their sons were being doubly disadvantaged and lacked independence. All parents felt their sons would never be able to live independently, requiring support in activities of daily living and their diabetes. In terms of independence and diabetes management, parents reported that co-morbid physical and mental conditions made diabetes selfmanagement difficult. They reported their sons had a basic understanding of routine and equipment requirements for testing blood glucose and administering insulin yet lacked comprehension of the wider implications of their condition. They also grappled with the dilemma of allowing their sons to self-manage their diabetes by seeking to promote learning and independence while recognising potential risks. In relation to independence and responsibility, families described the necessity for others, both inside and outside the home, to be involved in their sons' diabetes care, and were of the view that they, the parents, always had part of this responsibility and had to educate carers and teachers over the years. 
The first theme identified in Cardol et al., (36) study was the perceived severity of diabetes, where most caregivers did not view diabetes as a serious condition unless insulin was required or when loss of consciousness might occur. Another theme highlighted was perceptions regarding the motivation and capabilities of the person with diabetes where respondents stated they did not always trust the service user as they might eat in secret and steal food. Nine caregivers were negative about the capability of the person with ID and diabetes to learn and self-manage diabetes to some extent. The knowledge and educational needs of the caregivers was further identified as a pivotal theme where nurses were found to have more knowledge than social workers and some social workers underwent additional training to learn about diabetes, which covered insulin administration but not self-management. Some participants wanted more diabetes knowledge whereas others relied on the knowledge of specialist health professionals. Another theme that emerged from this study was self-management support where all caregivers cited medical management, such as injections, blood glucose tests and controlling food intake as special care or support they provide in relation to diabetes management and some also reported support in teaching how to deal with dietary issues. Some participants stated that it was not always clear who bears responsibility for diabetes management and most stated they provided support that was more directed towards control and prohibition and that informing and engaging in self-management was rare. Caregivers who had positive attitudes towards the learning ability of their serviced user highlighted trust, a positive approach, creative solutions and flexibility as key components of their support. Personal goal setting, appointments and structure were found to be additional important aspects of support. Contextual factors, such as consistency within the team and collaboration with health care professionals and family members were identified as additional important support factors. Issues which impeded carers' motivation to encourage diabetes self-management were identified as: a lack of diabetes education material, other residents in the community housing that required intensive support and inadequate equipment. The final theme identified was balancing health management and quality of life where all carer participants experienced a dilemma in that they aspired to provide good diabetes care whilst promoting personcentred support, which they viewed as conflicting at times.

The findings that emerged from Hale et al., (35) study were that 2 of the participants were unaware that the person they supported had an individualised diabetes 
management plan despite this being readily available; 1 stated that staff need to check that the person they support reads their blood glucose levels correctly, to undertake hand washing and ensure an appropriate diet, with another raising concern about issues with numeracy by a service users which affected self-management abilities.

In terms of the methodological limitations of the studies, demographic data were only obtained from participants in 1 study (36). Females were over represented, as were social workers, and no distinction was made between participants' ethnicity, age and personal experience with diabetes across studies. Having only utilised 2 sets of parents, Hillege et al. (37) had a small sample and, while 14 people participated in Hale et al., (35) study as staff informants, only 4 participants' views are reported. The methodological issues with the Hale (35) study are considered in section 3.4. The remaining 2 studies utilised valid qualitative analysis techniques, with Hillege et al., (37) using manifest and latent content analysis (41) and Cardol et al., (36) using Grounded Theory. In the study by Cardol et al., (36), 2 researchers evaluated the interviews, discussed the data and coding and made comparisons. No reference was made to independent review in the study by Hillege et al., (37) which is necessary to ensure confidence in the primary researcher's interpretation of the data.

The results indicate that both family and professional caregivers lack confidence in the capabilities of individuals with ID to self-manage their diabetes. Caregivers also reported a lack of adequate support, limited knowledge about diabetes management and an overarching sense of responsibility for managing the individual's diabetes. The factors which were most commonly identified by caregivers that restricted diabetes self-management were limited access to education materials, inadequate equipment, the intense support needs of other service users, and those with diabetes and additional physical and mental health comorbidities.

\section{DISCUSSION}

The findings from the quantitative studies indicated that there is no clearly identified prevalence of diabetes in people with ID within the available literature, however, the evidence points to significantly higher prevalence rates for these individuals than the non-ID population. The results from the qualitative studies which obtained data from 
people with ID about managing their diabetes suggested respondents had a basic understanding of diabetes and many want to know more. People with ID valued diabetes advice and support from family members and professional care staff, however, opportunities to learn to master self-management skills were not routine. The findings from the studies which obtained the views of caregivers indicated that some lacked confidence in the capabilities of people with ID to self-manage their diabetes. Caregivers also reported a lack of adequate support with, and knowledge and training in, diabetes management. Furthermore, they identified factors which restricted diabetes self-management, such as limited education materials and inadequate equipment. The limitations of the included studies have been discussed in depth in sections 3.3 to 3.5. and within tables 3,4 and 5 . These relate to an over representation of male participants within the prevalence studies and an over representation of females within the experiential studies; self-reporting of diabetes in 5 of the prevalence studies; small sample sizes and poor sampling techniques in the experiential studies and a lack of detailed participant demographic data across the majority of included studies.

The suggestion that diabetes may be higher in people with ID in comparison to the general population is unsurprising considering research highlighting that people with ID are more likely to experience the major diabetes risk factors - poor nutrition; high fat, sugar and salt and low fibre diet; high blood pressure; leading a sedentary lifestyle with limited physical activity; being obese and being of an increased age (7-13). Furthermore, several studies have highlighted issues more frequently experienced by people with ID specifically, such as social exclusion $(42,43)$ and limited access to medical care (44) and leisure facilities (45), which might place them at additional risk of developing diabetes. In finding that people with ID may be significantly more likely to develop diabetes than the general population across 8 studies, this review has identified a health inequality which policy makers, service planners and diabetes services should take into account to ensure they can respond accordingly to ensure adjustments are made to meet the needs of this group. This is necessary upon considering the predicted increases in rates of diabetes (14) and ID (15) and the increasing life expectancy of people with ID (16).

The range in diabetes prevalence figures in relation to people with ID identified in this review presents a challenge for practitioners, service planners and policy makers to 
provide adequate services to meet demand now and in the future. It has been argued that such differences in prevalence relate to whether studies report diagnosed or undiagnosed diabetes, the operational definition of ID used within them and whether individuals are identified or labelled with a diagnosed ID (46). Three studies (22, 19, 24) specifically looked at diabetes in people with Down's syndrome or Prader-Willi which might account for the variance in prevalence figures between their findings and those from studies assessing diabetes prevalence in people with ID in general. Interestingly, Down Syndrome was identified as a factor that significantly increases the risk of diabetes in people with ID in 1 study (22) yet 2 studies suggested diabetes risk is higher in people who have a cause of ID other than Down $\square$ s syndrome (20; 28). Five studies identified additional factors which were significantly associated with diabetes in people with ID including co-morbid severe mental health issues $(26,52)$, obesity $(30,52)$, milder forms of ID and an ability to shop for groceries independently (20) and being at an advanced age (54). In light of the apparent considerable differences in diabetes prevalence for people affected, these factors should be taken into consideration when measuring prevalence in this subset of the population.

The majority of the studies included in this review lacked detailed participant demographic information, such as genetic syndromes, in addition to other personal circumstances which may be factors that influenced the reported prevalence rates. Only 1 of the prevalence studies (19) made a distinction between participants' diabetes type and most made no distinction between participants' living arrangements, level of ID or any comorbidity they experienced. The relevance of this is important when considering the few studies which did report distinctions found that certain factors were associated with varying diabetes prevalence rates described in this paper. In addition to these distinctions, identifying whether research participants with ID have type 1 or type 2 diabetes could help inform more targeted prevention strategies and interventions for those at higher risk of developing diabetes. The majority of studies which gathered data on the views and experiences of people with ID and diabetes and their family members or professional carers also failed to make distinctions between participants $\square$ level of ID, which may have explained the variety in views and opinions expressed. The terms "mild", "moderate" and "severe or profound" ID suggest distinct categories which are well-recognised within ID services and research, however, it seems reasonable to suggest that they are not well recognised by diabetes practitioners or researchers who have limited expertise in ID. 
Identifying how diabetes specifically affects people with mild, moderate or severe and profound ID could help formulate more appropriate, person-centred interventions.

An important outcome of this review is the finding that 35 people with ID participated in the 3 studies exploring their experiences of having diabetes. Having an ID is often an exclusion criteria for participating in research, yet the included studies suggest that people with ID participated with ease and provided valuable insights into their condition and the services they received. People with ID have traditionally been excluded from decisions about their health care and self-management because of assumptions about their cognitive limitations (47), however, these studies shed new light on their capabilities and aspirations with regard to diabetes management. One of the studies (33) reported utilising communication or comprehension aids which may have helped reduce the risk of aquiescence bias and ensure a good level of participation.

Learning about diabetes and how to self-manage the condition are the mainstays of diabetes intervention programmes offered by health services to people with diabetes in the general population (48). In the United Kingdom, people are encouraged to attend one of 2 structured education programs depending on their diabetes type; DAFNE, for adults with type 1 diabetes, educating them about intensive insulin therapy (www.dafne.uk.com), or DESMOND, for adults with type 2, which focusses on addressing diet and exercise (www.desmond-project.org.uk). The results of this study suggested people with ID want to know more about diabetes, however, neither of these diabetes education programs are routinely offered to people with ID at a level that is appropriate to their learning needs. This is a barrier that contributes to the health inequalities experienced by some people with ID, who are denied access to health education appropriate to their needs. A concerning finding from this review is that professional care staff lacked confidence in the ability of people with ID to selfmanage their diabetes and reported that this is not routinely encouraged suggesting they are not offered the opportunity to be an active participant in their treatment. It has been previously recognised that with adequate and appropriate education and support, people with ID can achieve a level of autonomous diabetes care (49) and therefore steps need to be taken to strengthen this where appropriate. Professional care staff also reported a lack of diabetes education and resources despite staff and family members being cited as the main sources of advice, support and guidance by 
people with ID and diabetes in the included studies. Therefore, in addition to ensuring people with ID and diabetes obtain access to appropriate diabetes education, diabetes training and resources are also vital for the people who support them to enhance their knowledge and allow them to empower people with ID to self-manage their diabetes as far as possible.

To the best of our knowledge, only 1 other systematic review has been published to date in relation to diabetes and people with ID. McVilly et al., (50) reviewed 13 studies with an aim of identifying the prevalence of diabetes in people with intellectual and developmental disabilities (IDD), 3 studies addressing the impact of diabetes on the health and well-being of this population and 3 studies addressing the management of their diabetes. The results of McVilly et al., paper concur with the findings from this systematic review in that the prevalence of diabetes in people with ID / IDD remains uncertain. The current paper obtained a mean prevalence figure of $8.3 \%$ from the results reported in the included studies which is a similar finding to McVilly et al., $8.7 \%$ mean prevalence figure averaged from their included studies. However, the reviews differ in the range of reported prevalence figures with the included papers in the current review $\square$ s findings ranging from $0.4 \%$ to $25 \%$ and those included in the McVilly review ranging from $3.4 \%$ to $18.5 \%$. This can be explained by the inclusion of 10 studies $(19,21-26,28,30,32)$ in the current review which were not included in the McVilly review. The current review specifically made reference to the fact that 11 of the included prevalence studies suggested diabetes occurs more frequently in people with ID than the general population, with 8 of these reaching statistical significance, which was not directly reported by McVilly et al. By exploring the impact of diabetes on the health and wellbeing of people with ID and diabetes and the management of their diabetes, McVilly et al., cited results from 4 studies also included in the current review (33-36). However, the current review analysed these studies according to those which reported the views and experiences of people with ID and diabetes and those which reported the views of the people who provide care and support, thereby including a study (37) which considered the views of family carers and was not included in the McVilly review. Therefore, the current review reports the views and experiences of caregivers which McVilly et al., did not directly explore.

McVilly et al., (50) suggested the quality of evidence on which to base prevention and management strategies is variable, concurring with the analysis undertaken across 
the prevalence studies included in this paper. The current review offered a robust review of the studies, incorporating two separate assessments of quality in consideration of the quantitative nature of the prevalence studies and qualitative nature of the studies reporting the views and experiences of people with ID and diabetes and the people who care for them, and found all but 2 of the prevalence studies to be of strong or moderate quality and all but one of the qualitative studies to be of high quality. A similar finding from this review and that undertaken by McVilly et al., (50) is that that none of the prevalence studies included in their review made a distinction between the diabetes type of participants with ID and diabetes, a methodological limitation that was also identified in the current review as only one of the included studies made this distinction. The current study also highlighted a lack of detailed participant demographic data across the majority of included studies, placing particular importance on a lack of distinction made between the level of ID participants experienced, their living arrangements and any co-existing conditions they had as well as a lack of demographic information about participants in 2 of the studies obtaining views from carers. Another similar finding between McVilly at al., (50) and the current review is the identification of the need for further research to inform policy and practice in this area. In the view of the authors of the current study, work is required to develop methodologies, evaluation tools, educational resources and diabetes care support services appropriate to the needs of people with ID. The current review also recommends the feasibility of adapting mainstream diabetes education packages to meet the needs of people with ID as an area where further research is required.

\section{CONCLUSIONS}

In conclusion, from systematically reviewing the current literature relating to people with ID and diabetes, it is apparent that further research is required to both clarify diabetes prevalence and to devise appropriate management strategies that enable family cares and professionals to better support the intellectually disabled to manage their diabetes. This is important as, in addition to one that is aging and increasing, this population already presents with comorbid physical and mental health conditions which could heighten their risk of developing diabetes or exacerbate a current diagnosis. It is important to ensure that research, particularly prevalence studies, pays attention to participant demographics to provide a more representative picture of diabetes in people with ID. It is essential to include people with ID as participants in 
future research to gain valuable evidence on their needs, ability to self-manage their diabetes and how education programmes and services can be made accessible to them. Furthermore, access to diabetes care should be person-centred, considering people with IDs' learning and communication needs, and equal to that available to non-disabled individuals. In light of the apparent knowledge gap and lack of diabetes self-management amongst people with ID, it seems sensible to explore the feasibility of adapting mainstream diabetes education and self-management programs, such as DESMOND and DAFNE in the UK, to suit the needs of people with ID and diabetes. Inviting family members and care staff to attend would enhance understanding, reinforce learning and enable people with ID to self-manage their condition as effectively as any other diabetic. It is anticipated that undertaking this systematic review will raise awareness of the under researched state of diabetes care for people with ID and will encourage further study. This, in turn, may enable service providers and commissioners to effect change and ensure that these individuals can access the same diabetes care as the non-disabled.

\section{ACKNOWLEDGEMENTS}

The corresponding author undertook the initial literature review, synthesis and write up of the results. All authors contributed to and assisted with the analysis, preparation, drafting and revising of the manuscript.

The authors declare that there is no conflict of interest. 


\section{REFERENCES}

( ${ }^{*}$ Denotes studies included in the systematic review)

1. Schalock R. L., Borthwick-Duffy S. A., Bradley V. J., Buntinx W. H. E., Coulter D. L., Craig E. M., Gomez S. C., Lachapelle Y., Luckasson R., Reeve A., Shogren K. A., Snell M. E., Spreat S., Tassé M. J., Thompson J. R., Verdugo-Alonso M. A., Wehmeyer M. L., Yeager M. H. (2010) Intellectual Disability: Definition, Classification, and Systems of Supports (11th edition) Washington, D.C.: American Association on Intellectual and Developmental Disabilities (AAIDD)

2. Gillberg C., \& Soderstrom, H. (2003). Learning Disability. Seminar. The Lancet, 362 (6), pp 811-821

3. Emerson E., Hatton C., Robertson J., Roberts H., Baines S., Evison F., Glover G. (2012b) People with Learning Disabilities in England: 2011. Durham: Improving Health \& Lives: Learning Disabilities Observatory

4. Wen X. (2004) Estimates of prevalence of intellectual disability in Australia. Journal of Intellectual and Developmental Disability, 29, pp 284-289.

5. Glover G., Emerson, E., Eccles R. (2012) Using local data to monitor the Health Needs of People with Learning Disabilities. Durham: Improving Health \& Lives: Learning Disabilities Observatory

6. Jansen D. E., Krol B., Groothoff J. W., Post D. (2004) People with intellectual disability and their health problems: A review of comparative studies. Journal of Intellectual Disability Research, 48 (2), pp 93-102.

7. Mokdad A., Earl S., Ford A., Barrowman B., Dietz W., Vinicor F.et al. (2003) Prevalence of obesity, diabetes, and obesity-related health risk factors, 2001. Journal of the American Medical Association, 289 (1), pp 76-79.

8. Ewing G., McDermott S., Thomas-Koger M., Whitner W., Pierce K. (2004) Evaluation of a cardiovascular health program for participants with mental retardation and normal learners. Health Education and Behaviours, 31 (1), pp 77-87 
9. McGuire B. E., Daly P. Smyth F. (2007) Lifestyle and health behaviours of adults with an intellectual disability. Journal of Intellectual Disability Research, 51 (7), pp 497-510.

10. Bartlo P., Klein P. J. (2011) Physical activity benefits and needs in adults with intellectual disabilities: Systematic Review of the Literature. American Journal of Intellectual and Developmental Disabilities, 116 (3), pp 220-232

11. Merrick J. \& Morad M. (2010) 'Cardiovascular disease', in: O'Hara J. O., McCarthy J., Bouras N. (editors) Intellectual Disability and III Health, University Press, Cambridge, pp. 73-78.

12. Merrick J., Davidson P. W., Morad M., Janicki M. P., Wexler O. \& Henderson C. M. (2004) Older adults with intellectual disability in residential care centres in Israel: health status and service utilization. American Journal on Mental Retardation, 109 (5), pp 413-420

13. Sohler N., Lubetkin E., Levy J., Soghomonian C., Rimmerman A. (2009) Factors associated with obesity and coronary heart disease in people with intellectual disabilities. Social Work in Health Care, 48 (1), pp 76-89.

14. World Health Organization (WHO)(2006) The Global Burden: Diabetes and Impaired Glucose Tolerance. Retrieved from: http://www.idf.org/sites/default/files/The Global Burden.pdf $\quad$ (Accessed November 2013).

15. Emerson E, Hatton C (2008) People with learning disabilities in England. Lancaster: Centre for Disability Research (CeDR), Lancaster University.

16. Bittles A. H., Petterson B. A., Sullivan S. G., Hussain R., Glasson, E. J., Montgomery P. D. (2002) The influence of intellectual disability on life expectancy. The Journals of Gerontology Series A: Biological Sciences and Medical Sciences, 57 (7). pp M470-M472.

17. Effective Public Health Practice Project (2008). Quality Assessment Tool for 
Quantitative Studies. Retrieved from http://www.nccmt.ca/registry/pdf/en.html (Accessed November 2013)

18. Hannes K. (2011) 'Critical appraisal of qualitative research', in: Noyes J., Booth A., Hannes K., Harden A., Harris J., Lewin S., Lockwood C. (editors), Supplementary Guidance for Inclusion of Qualitative Research in Cochrane Systematic Reviews of Interventions. Cochrane Collaboration Qualitative Methods Group, 2011. Retrieved from http://carmg.cochrane.org/supplemental-handbook-guidance (Accessed November 2013)

19. * Butler J. V., Whittington J. E., Holland A. J., Boer H., Clarke D., Webb T. (2002). Prevalence of, and risk factors for, physical ill-health in people with Prader-Willi syndrome: a population-based study. Developmental Medicine and Child Neurology, 44 (4), pp 248-255

20. * de Winter C. F., Bastiaanse L. P., Hilgenkamp T. I. M., Evenhuis H. M., Echteld M. A. (2012) Cardiovascular risk factors (diabetes, hypertension, hypercholesterolemia and metabolic syndrome) in older people with intellectual disability: Results of the HA-ID study. Research in Developmental Disabilities, 33 (6), pp 1722-1731

21. * de Winter C. F., Hermans H., Evenhuis H. M., Echteld M. A. (2013) Associations of symptoms of anxiety and depression with diabetes and cardiovascular risk factors in older people with intellectual disability. Journal of Intellectual Disability Research, 2013 (online)

22. *Goldacre M. J., Wotton C. J., Seagroatt V., Yeates D. (2004) Cancers and immune related diseases associated with Down's syndrome: a record linkage study. Archives of Disease in Childhood, 89 (11), pp1014-1017

23. * Havercamp S., Scandlin D., Roth M. (2004) Health disparities among adults with developmental disabilities, adults with other disabilities, and adults not reporting disability in North Carolina. Public Health Reports, 119 (4), pp 418-26.

24. * Hoybye C.(2004) Endocrine and metabolic aspects of adult Prader-Willi syndrome with special emphasis on the effect of growth hormone treatment. Growth 
Hormone and IGF Research, 14 (1), pp1-15.

25. * Kerr A. M., McCulloch D., Oliver K., McLean B., Coleman E., Law T., Beaton P., Wallace S., Newell E., Eccles T., Prescott R. J. (2003). Medical needs of people with intellectual disability require regular reassessment, and the provision of client- and carer-held reports. Journal of Intellectual Disability Research, 47 (2), pp 134-145

26. * Lunsky Y., Lin E., Balogh R., Klein-Geltink J. (2011) Diabetes Prevalence Among Persons With Serious Mental Illness and Developmental Disability. Psychiatric Services, 62 (8), pp 830.

27. * McDermott S., Moran R., Platt T. Dasari S. (2006) Variation in health conditions among groups of adults with disabilities in primary care. Journal of Community Health, 31 (3), pp 147-159.

28. *Morin, D., Mérineau-Côté, J., Ouellette-Kuntz, H., Tassé, M. J., Kerr, M. (2012) A Comparison of the Prevalence of Chronic Disease Among People with and Without Intellectual Disability. American Journal on Intellectual and Developmental Disabilities, 117 (6), pp 455-463

29. * Reichard A. \& Stolzle, H. (2011). Diabetes Among Adults with Cognitive Limitations Compared to Individuals with No Cognitive Disabilities. Intellectual and Developmental Disabilities, 49 (3), pp 141-154.

30. * Rimmer J. H., Yamaki K., Davis Lowry M., Wang E., Vogel L. C. (2010) Obesity and obesity-related secondary conditions in adolescents with intellectual / developmental disabilities. Journal of Intellectual Disability Research, 54 (9), pp 787794

31. * Shireman T., Reichar A., Nazir N., Backes J., Pharm D., Griener A. (2010) Quality of diabetes care for adults with developmental disabilities. Disability and Health Journal, 3 (3), pp 179-85.

32. * Straetmans J., Van Schrojenstein Lantman-de Valk H. M. J., Schellews F. G., Dinant G. J. (2007) Health problems of people with intellectual disabilities: the impact 
for general practice. British Journal of General Practice, 57, pp 64-66.

33. * Cardol M., Rijken M., van Schrojenstein Lantman de Valk H. (2012b) People with mild to moderate intellectual disabilities talking about their diabetes and how they manage. Journal of Intellectual Disability Research, 56 (4) 351-360.

34. * Dysch C., Chung M. C., Fox J. (2012) How Do People with Intellectual Disabilities and Diabetes Experience and Perceive their Illness? Journal of Applied Research in Intellectual Disabilities, 25 (1), pp 39-49

35. * Hale L. A., Trip H. T., Whitehead L. Conder J. (2011) Self-management abilities of diabetes in people with an intellectual disability living in New Zealand. Journal of Policy and Practice in Intellectual Disabilities, 8 (4), pp 223-231

36. * Cardol M., Rijken M., van Schrojenstein Lantman de Valk H. (2012a) Attitudes and dilemmas of caregivers supporting people with intellectual disabilities who have diabetes. Patient Education and Counseling, 87 (3), pp 383-388

37. * Hillege S., Evans J., Gallagher S. (2013). The challenges for families managing an adolescent with an intellectual disability and type 1 diabetes. Australian Journal of Advanced Nursing, 20 (3), pp 26-32

38. Thomas, D. R. (2006). A general inductive approach for analysing qualitative evaluation data. American Journal of Evaluation, 27, 237-246.

39. Leventhal H., Benyamini Y., Brownlee S., Diefenbach M., Leventhal E. A. \& Patrick-Miller L. (1997) Illness representations: theoretical foundations. In: Perceptions of Health and IIIness: Current Research and Applications (eds K. J. Petrie \& J.A. Weinman), pp. 19-46. Harwood Academic, Amsterdam.

40. Corbin J. \& Strauss A. (2008) Basics of Qualitative Research; Techniques and Procedures for Developing Grounded Theory. Sage Publications, Thousand Oaks, California.

41. Berg, B. 2007. Qualitative research methods for social sciences (6th ed) Boston: 
Allyn and Bacon.

42. Disability Rights Commission (DRC) (2006) Equal Treatment: Closing the Gap. A Formal Investigation into Physical Health Inequalities Experienced by People with Learning Disabilities and / or Mental Health Problems. London: DRC

43. Leonard H., Petterson B., De Klerk N., Zubrick S. R., Glasson E., Sanders R., Bower C. Association of sociodemographic characteristics of children with intellectual disability in Western Australia. Social Science \& Medicine 2005, 60 (7), pp 1499-1513.

44. Emerson E. \& Baines S. (2010) Health inequalities \& people with learning disabilities in the UK. Durham: Improving Health \& Lives: Learning Disabilities Observatory.

45. Messent P. R., Cooke C. B. Long J. (1998) Physical activity, exercise and health of adults with mild and moderate learning disabilities. British Journal of Learning Disabilities, 26 (1), pp 17-22.

46. Taggart L., Coates V., Truesdale-kennedy M. (2013) Management and quality indicators of diabetes mellitus_in people with intellectual disabilities._Journal of Intellectual Disability Research, 57 (12), pp 1152-1163

47. Bazzano A. T., Zeldin A. S., Shihady Diab, I. R., Garro N. M., Allevato N. A., Lehrer D. (2009) The Healthy Lifestyle Change Program a pilot of a community-based health promotion intervention for adults with developmental disabilities. American Journal of Preventative Medicine, 37 (6 Supplement 1), pp S201-S208

48. National Institute of Clinical Excellence (NICE)(2011) Quality Standards Programme. NICE cost impact and commissioning assessment for diabetes in adults. London: NICE. Available from: http://www.nice.org.uk/nicemedia/live/13827/60175/60175.pdf $\quad$ (Retrieved November 2013)

49. Rey-Conde T., \& Lennox, N. (2007) Delivering diabetes care to people with intellectual disability. Diabetes Voice, 52 (2), pp 16-18 
50. McVilly K., McGillivray J., Curtis A., J. Lehmann J., Morrish L., Speight J. (2014) Diabetes in people with an intellectual disability: a systematic review of prevalence, incidence and impact. Diabetetic Medicine, 31, pp 897-904

51. * Sohler N., Lubetkin E., Levy J., Soghomonian C., Rimmerman A. (2009) Factors Associated with Obesity and Coronary Heart Disease in People with Intellectual Disabilities. Social Work Health Care, 48 (1), pp 76-89.

52. * McDermott S., Moran R., Platt T., Dasari S. (2007) Prevalence of Diabetes in Persons with Disabilities in Primary Care. Journal of Developmental and Physical Disabilities, 19 (3), pp 263-271.

53. * Wong C. W. (2011) Adults With Intellectual Disabilities Living in Hong Kong's Residential Care Facilities: A Descriptive Analysis of Health and Disease Patterns by Sex, Age and Presence of Down Syndrome. Journal of Policy and Practice in Intellectual Disabities, 8 (4), pp 231-238.

54. * Haveman M., Perry J., Salvador-Carulla L., Noonan Walsh P., Kerr M., Van Schrojenstein Lantman-de Valk H., et al. (2011) Ageing and health status in adults with intellectual disabilities: Results of the European POMONA II study. Journal of Intellectual and Developmental Disability, 36 (1), pp 49-60.

55. * Shah A., Bruce M., Willson C., Malik M., Gaffney K. (2006) The care of people with diabetes in care homes within a primary care trust. Journal of Diabetes Nursing, 10 (8), pp 289-296.

56. * Chen G., Tan B-K., Sun X., Meng X., Jiwa M. (2011) A preliminary report on the medical profile of disabled persons living in Zhabei District, Shanghai, Mainland China. Quality in Primary Care, 19, pp 233-244.

57. * Tyler C. V., Schramm S., Karafa M., Tang A. S., Jain A. (2010) Electronic Health Record Analysis of the Primary Care of Adults With Intellectual and Other Developmental Disabilities. Journal of Policy and Practice in Intellectual Disabilities, 7 (3), pp 204-210 
58. * van Schrojenstein Lantman-de Valk H., van den Akker M., Maaskant M. A., Haveman M. J., Urlings H. F. J., Kessels A. G. H. et al. (1997) Prevalence and incidence of health problems in people with intellectual disability. Journal of Intellectual Disability Research, 41 (1), pp 42-51.

Websites:

DAFNE www.dafne.uk.com (Accessed November 2013)

DESMOND www.desmond-project.org.uk (Accessed November 2013) 
Fig. 1 Flow diagram of data retrieved at each stage of the review

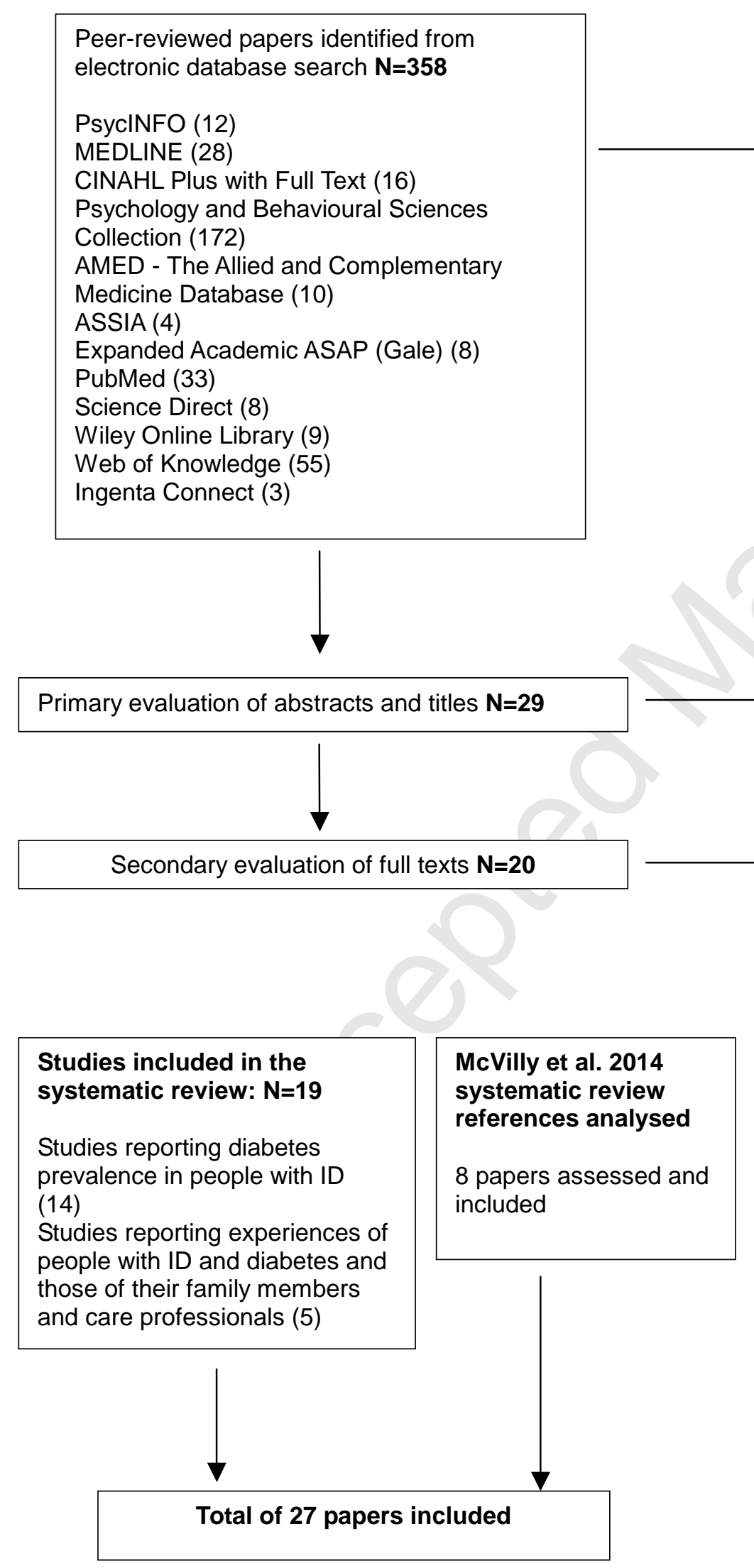

Excluded: $\mathrm{N}=1$

Did not meet inclusion criteria (1)

Excluded: $\mathbf{N}=\mathbf{9}$

Did not meet inclusion criteria:

Not original research, theoretical papers (3)

Participants did not have diabetes and an intellectual disability (3) Not published in English (2) Did not examine the prevalence of diabetes or experiences of diabetes (1) 
Table 1. Quality assessment of the 22 studies which reported diabetes prevalence in people with ID

\begin{tabular}{|c|c|c|c|c|c|c|}
\hline Study & $\underline{\text { Representativeness }}$ & $\begin{array}{l}\text { Component } \\
\text { Design }\end{array}$ & $\begin{array}{l}\text { Rating } \\
\text { Confounders }\end{array}$ & Validity & Dropout & $\begin{array}{l}\text { Global } \\
\text { Rating }\end{array}$ \\
\hline de Winter et al. (2013) & Moderate & Moderate & Strong & Strong & Strong & Strong \\
\hline de Winter et al. (2012) & Moderate & Strong & Strong & Strong & Strong & Strong \\
\hline Morin et al (2012) & Moderate & Moderate & Strong & Strong & Weak & Moderate \\
\hline Lunsky et al. (2011) & Moderate & Moderate & Moderate & Strong & Strong & Strong \\
\hline $\begin{array}{l}\text { Reichard \& Stolzle } \\
\text { (2011) }\end{array}$ & Moderate & Moderate & Weak & Strong & Strong & Moderate \\
\hline Wong (2011) & Moderate & Moderate & Strong & Weak & Strong & Moderate \\
\hline Haveman et al. (2011) & Moderate & Moderate & Strong & Strong & Weak & Moderate \\
\hline Chen (2011) & Moderate & Weak & Strong & Strong & Moderate & Moderate \\
\hline Rimmer et al. (2010) & Moderate & Strong & Weak & Strong & Strong & Moderate \\
\hline Shireman et al. (2010) & Strong & Strong & Strong & Strong & Strong & Strong \\
\hline $\begin{array}{l}\text { Straetmans et al. } \\
(2007)\end{array}$ & Moderate & Moderate & Weak & Strong & Strong & Moderate \\
\hline Tyler et al. (2010) & Moderate & Moderate & Strong & Strong & Weak & Moderate \\
\hline McDermott et al. (2007) & Moderate & Moderate & Strong & Strong & Strong & Strong \\
\hline McDermott et al. (2006) & Weak & Moderate & Weak & Strong & Strong & Weak \\
\hline Sohler et al. (2009) & Moderate & Moderate & Strong & Strong & Strong & Strong \\
\hline Goldacre et al. (2004) & Moderate & Strong & Moderate & Strong & Strong & Strong \\
\hline $\begin{array}{l}\text { Havercamp et al. } \\
\text { (2004) }\end{array}$ & Moderate & Moderate & Weak & Strong & Strong & Moderate \\
\hline Shah et al. (2006) & Weak & Moderate & Strong & Strong & Weak & Weak \\
\hline Hoybe et al. (2004) & Moderate & Moderate & Weak & Strong & Strong & Moderate \\
\hline Kerr et al. (2003) & Moderate & Strong & Weak & Strong & Moderate & Moderate \\
\hline Butler et al. (2002) & Moderate & Strong & Moderate & Strong & Moderate & Strong \\
\hline $\begin{array}{l}\text { Van Schrojenstein } \\
\text { Lantman-de Valk et al. } \\
\text { (1997) }\end{array}$ & Moderate & Moderate & Strong & Strong & Moderate & Strong \\
\hline
\end{tabular}


Table 2. Quality assessment of the 5 studies which reported caregivers' views / experiences of diabetes in people with ID

\begin{tabular}{|c|c|c|c|c|c|}
\hline Study & $\underline{\text { Credibility }}$ & $\begin{array}{l}\text { Component } \\
\text { Transferability }\end{array}$ & $\begin{array}{c}\text { Rating } \\
\text { Dependability }\end{array}$ & Confirmability & Global Rating \\
\hline Hillege et al. (2013) & $\checkmark$ & $x$ & $x$ & $x$ & Low \\
\hline Cardol et al. (2012a) & $\checkmark$ & $x$ & $\checkmark$ & $\checkmark$ & High \\
\hline Cardol et al. (2012b) & $\checkmark$ & $\checkmark$ & $\checkmark$ & $\checkmark$ & High \\
\hline Dysch et al (2012) & $\checkmark$ & $\checkmark$ & $\checkmark$ & $\checkmark$ & High \\
\hline Hale et al. (2011) & $\checkmark$ & $x$ & $\checkmark$ & $y$ & High \\
\hline
\end{tabular}


Table 3: summary of studies reporting diabetes prevalence in people with intellectual disabilities

\begin{tabular}{|c|c|c|c|c|c|c|}
\hline Author & Participants characteristics & Aims & $\begin{array}{l}\text { Primary study aim } \\
\text { Directly / indirectly } \\
\text { addressed diabetes } \\
\text { prevalence }\end{array}$ & $\begin{array}{l}\text { How diabetes prevalence was } \\
\text { measured }\end{array}$ & Findings & $\begin{aligned} \text { Limitations } \\
\\
>\quad \text { Design } \\
>\quad \text { Sampling } \\
>\quad \text { Measures }\end{aligned}$ \\
\hline $\begin{array}{l}\text { de Winter et } \\
\text { al. (2013; } \\
\text { 2012) } \\
\text { The } \\
\text { Netherlands }\end{array}$ & $\begin{array}{l}\text { Sample size: } 980 \\
\text { Gender: Females - } 48.7 \% \\
\quad \text { Males - } 51.3 \% \\
\begin{array}{l}\text { Age: low - } 50 \text { high - } 93 \\
\text { mean - } 61\end{array} \\
\text { Mode ethnicity: none } \\
\text { identified } \\
\text { Mode level of ID: moderate } \\
\text { Mode diabetes type: none } \\
\text { identified } \\
\text { Mode genetic syndrome: } \\
\text { none identified } \\
\text { Mode comorbidity: Anxiety } \\
\text { Mode Living arrangement: } \\
\text { Community housing }\end{array}$ & $\bar{D}$ & $\begin{array}{l}\text { Exploring the } \\
\text { association between } \\
\text { depression, anxiety } \\
\text { and diabetes in older } \\
\text { people with ID } \\
\text { Indirectly addressed } \\
\text { diabetes prevalence }\end{array}$ & $\begin{array}{l}\text { Diabetes defined as fasting serum } \\
\text { glucose }>6.1 \mathrm{mmol} / \mathrm{l} \text { and/or the use } \\
\text { of glucose lowering drugs. } \\
\text { Prevalence calculated by } \\
\text { percentage of participants meeting } \\
\text { the above criteria. }\end{array}$ & $\begin{array}{l}12.50 \% \text { of older people with ID have diabetes compared to } \\
9.1 \% \text { of people in the general population with diabetes } \\
(p>0.05) \\
\text { People with ID and diabetes were almost two and a half } \\
\text { times more likely to experience anxiety ( } p<0.05) \text {. } \\
\text { Significantly more at risk of having diabetes were people } \\
\text { with a less severe ID }(p<0.01) \text {, people with other causes } \\
\text { of ID than Down syndrome }(p<0.05) \text { and people who } \\
\text { were able to do groceries independently }(p<0.05)\end{array}$ & $\begin{array}{ll} & \text { Case control } \\
\text { No issues identified } \\
\text { Not all participants completed } \\
\text { physical assessments. No } \\
\text { distinction between diabetes } \\
\text { type. }\end{array}$ \\
\hline $\begin{array}{l}\text { Morin et al } \\
(2012) \\
\text { Canada }\end{array}$ & $\begin{array}{l}\text { Sample size: } 789 \\
\begin{array}{l}\text { Gender: Females - } 45 \% \\
\text { Males - } 55 \%\end{array} \\
\begin{array}{l}\text { Age: low - } 15 \text { high - } 82 \\
\text { mean - } 35\end{array} \\
\text { Mode ethnicity: none } \\
\text { identified } \\
\text { Mode level of ID: mild } \\
\text { Mode diabetes type: none } \\
\text { identified } \\
\text { Mode genetic syndrome: } \\
\text { Down's Syndrome } \\
\text { Mode comorbidity: Not } \\
\text { identified } \\
\text { Mode Living arrangement: } \\
\text { Not identified }\end{array}$ & D & $\begin{array}{l}\text { Compared the } \\
\text { prevalence of chronic } \\
\text { health problems in } \\
\text { people with ID with } \\
\text { people from the } \\
\text { general population } \\
\text { Directly addressed } \\
\text { diabetes prevalence }\end{array}$ & $\begin{array}{l}\text { Percentage of participants / carers } \\
\text { who responded to the questionnaire } \\
\text { reporting they / their family member } \\
\text { or service user had diabetes }\end{array}$ & $\begin{array}{l}8.30 \% \text { of people with ID have diabetes compared to } 5.1 \% \\
\text { of people in the general population with diabetes }(p>0.05) \\
\text { Diabetes was observed in only } 4.2 \% \text { of people with down's } \\
\text { syndrome whereas } 9.6 \% \text { of people without Down's } \\
\text { syndrome also had diabetes }(p<0.05)\end{array}$ & $\begin{array}{ll} & \text { Cross-sectional } \\
\text { Mail survey } \\
\text { No distinction between type of } \\
\text { diabetes and living } \\
\text { arrangements. Over- } \\
\text { representation of people aged } \\
18-44 \text { and people with } \\
\text { moderate ID }\end{array}$ \\
\hline
\end{tabular}




\begin{tabular}{|c|c|c|c|c|c|c|}
\hline $\begin{array}{l}\text { Lunsky et al. } \\
\text { (2011) } \\
\text { Canada }\end{array}$ & $\begin{array}{l}\text { Sample size: } 29,010 \\
\text { Gender: Females - } \\
\text { developmental disabilities } \\
(\mathrm{DD})=42.5 \%, \mathrm{DD} \text { plus } \\
\text { serious mental illness (DD \& } \\
\mathrm{SMI})=45.2 \% \\
\text { Males }-\mathrm{DD}=57.5 \%, \mathrm{DD} \& \\
\mathrm{SMI}=54.8 \% \\
\text { Age: low - not identified } \\
\text { high - not identified } \\
\text { mean - DD = 37, DD \& SMI = } \\
39 \\
\text { Mode ethnicity: none } \\
\text { identified } \\
\text { Mode level of ID: none } \\
\text { identified } \\
\text { Mode diabetes type: none } \\
\text { identified } \\
\text { Mode genetic syndrome: } \\
\text { none identified } \\
\text { Mode comorbidity: Serious } \\
\text { mental health issues } \\
\text { Mode Living arrangement: } \\
\text { Not identified }\end{array}$ & $D$ & $\begin{array}{l}\text { Comparing the } \\
\text { prevalence of diabetes } \\
\text { between the general } \\
\text { population, people with } \\
\text { DD and people with } \\
\text { DD who also have } \\
\text { serious mental health } \\
\text { issues } \\
\text { Directly addressed } \\
\text { diabetes prevalence }\end{array}$ & $\begin{array}{l}\text { Percentage of participants with a } \\
\text { diagnosis of diabetes accessed } \\
\text { from health records }\end{array}$ & $\begin{array}{l}7.1 \% \text { of people with DD have diabetes compared to } 4.9 \% \\
\text { of general population have diabetes } \\
\text { Diabetes prevalence increases to } 14 \% \text { in people with DD } \\
\text { and a serious mental health issue } \\
\text { When age and sex were controlled for, the odds of having } \\
\text { diabetes were } 1.84 \text { times higher }(\mathrm{Cl}=1.75-1.94) \text { among } \\
\text { those with developmental disability, compared with the } \\
\text { general population. They also calculated the odds of } \\
\text { having diabetes in people with a DD as well as a severe } \\
\text { mental health issue which was even higher (adjusted } \\
\text { OR=3.63, Cl=3.34-3.94). }\end{array}$ & $\begin{array}{ll} & \text { Cross-sectional } \\
& \text { No issues identified } \\
& \text { No distinction between level of } \\
& \text { DD or type of diabetes }\end{array}$ \\
\hline $\begin{array}{l}\text { Reichard \& } \\
\text { Stolzle } \\
(2011) \\
\text { United } \\
\text { States of } \\
\text { America }\end{array}$ & $\begin{array}{l}\text { Sample size: } \text { without } \\
\text { diabetes: weighted }=5 \\
1,693,953 ; \text { unweighted }=238 \text {, } \\
\text { with diabetes = weighted } \\
7,054,179 ; \text { unweighted }=866 \\
=1104 \text { combined unweighted } \\
\text { participants with cognitive } \\
\text { limitations } \\
\text { Gender: Females - with } \\
\text { diabetes }=50.6 \% \text {, without } \\
\text { diabetes }=56.8 \% \\
\quad \text { Males }- \text { with } \\
\text { diabetes }=49.4 \% \text {, without } \\
\text { diabetes }=43.2 \% \\
\text { Age: low }-18 \text { high }-64 \\
\text { mean - with diabetes }=52, \\
\text { without diabetes = 44 } \\
\text { Mode ethnicity: caucasian } \\
\text { Mode level of ID: none } \\
\text { identified } \\
\text { Mode diabetes type: none } \\
\text { identified }\end{array}$ & $>$ & $\begin{array}{l}\text { To explore the quality } \\
\text { of diabetes care for } \\
\text { people with ID } \\
\text { compared with the } \\
\text { general population } \\
\text { Indirectly addressed } \\
\text { diabetes prevalence }\end{array}$ & $\begin{array}{l}\text { Percentage of participants with a } \\
\text { diagnosis of diabetes accessed } \\
\text { from health records }\end{array}$ & $\begin{array}{l}\text { 18.5\% of people with ID have diabetes compared to } 3.7 \% \\
\text { of people in the general population with diabetes ( } p<0.05 \text { ) } \\
\text { The odds of an adult with cognitive limitations developing } \\
\text { diabetes was } 2.7 \text { ( } 95 \% \mathrm{Cl} 51.9-3.58 \text { ). } \\
\text { Individuals with cognitive limitations and diabetes } \\
\text { experienced substantially and significantly more chronic } \\
\text { diseases (asthma, arthritis, cardiac disease, high blood } \\
\text { pressure, high cholesterol and stroke) than did individuals } \\
\text { in the no disability group with diabetes. Moreover, adults } \\
\text { with cognitive limitations and diabetes who were over } 40 \\
\text { years old reported having four or more of these. } \\
\text { chronic diseases at prevalence rates up to } 19.7 \text { times } \\
\text { higher than the no disability group with diabetes in } \\
\text { the same age groups }\end{array}$ & $\begin{array}{ll} & \text { Cross-sectional } \\
\text { No issues identified } \\
\text { No distinction between level of } \\
\text { ID, type of diabetes and living } \\
\text { arrangements }\end{array}$ \\
\hline
\end{tabular}




\begin{tabular}{|c|c|c|c|c|c|}
\hline & $\begin{array}{l}\text { Mode genetic syndrome: } \\
\text { none identified } \\
\text { Mode comorbidity: High } \\
\text { blood pressure, high } \\
\text { cholesterol, } \\
\text { Mode Living arrangement: } \\
\text { Not identified } \\
\end{array}$ & & 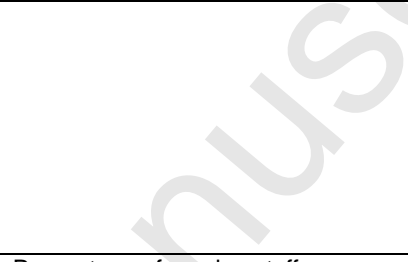 & & \\
\hline $\begin{array}{l}\text { Wong } 2011 \\
\text { Hong Kong }\end{array}$ & $\begin{array}{l}\text { Sample size: } 811 \\
\begin{array}{l}\text { Gender: Females - } 46.7 \% \\
\text { Males - } 53.3 \%\end{array} \\
\begin{array}{l}\text { Age: low - } 18 \text { high - } 79 \\
\text { mean - } 44\end{array} \\
\text { Mode ethnicity: Asian } \\
\text { (Hong Kong) } \\
\text { Mode level of ID: } \\
\text { severe/profound } \\
\text { Mode diabetes type: Not } \\
\text { identified } \\
\text { Mode genetic syndrome: } \\
\text { Down's Syndrome } \\
\text { Mode comorbidity: } \\
\text { Epilepsy, Cerebral Palsy } \\
\text { Mode Living arrangement: } \\
\text { Residential care }\end{array}$ & $\begin{array}{l}\text { To describe the health } \\
\text { status profile and } \\
\text { identify the healthcare } \\
\text { needs of adults with ID } \\
\text { residing in Hong Kong } \\
\text { residential care } \\
\text { facilities } \\
>\quad \text { Indirectly addressed } \\
\text { diabetes prevalence }\end{array}$ & $\begin{array}{l}\text { Percentage of nursing staff } \\
\text { members who responded to the } \\
\text { questionnaire reporting their patient } \\
\text { had diabetes }\end{array}$ & $\begin{array}{l}5.3 \% \text { of people with ID have diabetes diabetes compared } \\
\text { to } 3.3 \% \text { of people in the general population with diabetes } \\
4.1 \% \text { in males and } 6.6 \% \text { in females }\end{array}$ & $\begin{array}{l}\text { Cross-Sectional } \\
\text { No issues identified } \\
\text { No distinction between } \\
\text { diabetes type }\end{array}$ \\
\hline $\begin{array}{l}\text { Haveman et } \\
\text { al, 2011 } \\
\text { Europe-wide } \\
\text { (Austria, } \\
\text { Belgium, } \\
\text { Finland, } \\
\text { France, } \\
\text { Germany, } \\
\text { Ierand, } \\
\text { Italy, } \\
\text { Lithuania, } \\
\text { the } \\
\text { Netherlands, } \\
\text { Norway, } \\
\text { Romania, } \\
\text { Slovenia, } \\
\text { Spain, UK) }\end{array}$ & 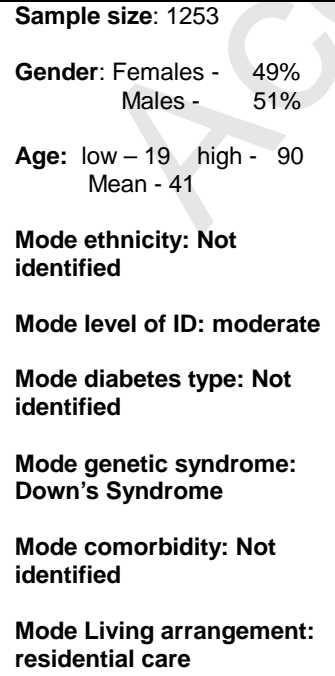 & $\begin{array}{l}\text { The research questions } \\
\text { in this article focus on } \\
\text { age-specific } \\
\text { differences relating to } \\
\text { environmental and } \\
\text { lifestyle factors, and } \\
\text { the } 17 \text { medical } \\
\text { conditions measured } \\
\text { by the POMONA } \\
\text { Checklist of Health } \\
\text { Indicators } \\
\text { Indirectly addressed } \\
\text { diabetes prevalence }\end{array}$ & $\begin{array}{l}\text { Percentage of participants who } \\
\text { stated they have diabetes during } \\
\text { P15 questionnaire }\end{array}$ & $\begin{array}{l}4.3 \% \text { of people with ID had diabetes. } \\
\text { A positive statisitical association was observed between } \\
\text { diabetes and advancing age }(p<.05)\end{array}$ & $\begin{array}{ll}\text { Cross-sectional } \\
\text { Self report } \\
\text { No distinction between } \\
\text { diabetes type }\end{array}$ \\
\hline
\end{tabular}




\begin{tabular}{|c|c|c|c|c|c|c|c|}
\hline $\begin{array}{l}\text { Chen } 2011 \\
\text { China }\end{array}$ & $\begin{array}{l}\text { Sample size: } 117 \\
\text { Gender: - Males - 56\% } \\
\text { Females - 44\% } \\
\text { Age: low - high - } \\
\text { mean - unkown, reported for } \\
\text { whole sample not just people } \\
\text { with ID. Range of ages } \\
\text { provided for people with ID, } \\
\text { mostly 0-39 years. } \\
\text { Mode ethnicity: Asian } \\
\text { (Chinese) } \\
\text { Mode level of ID: Not } \\
\text { identified } \\
\text { Mode diabetes type: Not } \\
\text { identified } \\
\text { Mode genetic syndrome: } \\
\text { Not identified } \\
\text { Mode comorbidity: Not } \\
\text { identified } \\
\text { Mode Living arrangement: } \\
\text { Not identified }\end{array}$ & $>$ & $\begin{array}{l}\text { To report available data } \\
\text { on the medical profile } \\
\text { of disabled persons } \\
\text { living in Zhabei District, } \\
\text { Shanghai, Mainland } \\
\text { China. It also aimed to } \\
\text { explore the association } \\
\text { between any medical } \\
\text { conditions, types and } \\
\text { severity of disabilities } \\
\text { and socio-demographic } \\
\text { factors. } \\
\text { Indirectly addressed } \\
\text { diabetes prevalence }\end{array}$ & $\begin{array}{l}\text { Percentage of people diagnosed } \\
\text { with diabetes after physical } \\
\text { medical examination }\end{array}$ & $3.4 \%$ of people with ID had diabetes & > & $\begin{array}{l}\text { Cross sectional } \\
\text { No issues identified } \\
\text { No distinction between level of } \\
\text { ID, diabetes type or living } \\
\text { arrangement }\end{array}$ \\
\hline $\begin{array}{l}\text { Rimmer et } \\
\text { al. (2010) } \\
\text { United } \\
\text { States of } \\
\text { America }\end{array}$ & $\begin{array}{l}\text { Sample size: } 461 \\
\text { Gender: Females }-32.5 \% \\
\quad \text { Males }-67.5 \% \\
\text { Age: low - } 13 \text { high - } 15 \\
\text { mean - } 14 \\
\text { Mode ethnicity: none } \\
\text { identified } \\
\text { Mode level of ID: not } \\
\text { identified } \\
\text { Mode diabetes type: not } \\
\text { identified } \\
\text { Mode genetic syndrome: } \\
\text { Down's Syndrome } \\
\text { Mode comorbidity: Autism } \\
\text { Mode Living arrangement: } \\
\text { Not identified }\end{array}$ & & $\begin{array}{l}\text { Compared diabetes } \\
\text { rates in youths with ID } \\
\text { and were obese with } \\
\text { youths with ID who } \\
\text { weren't obese } \\
\text { Directly addressed } \\
\text { diabetes prevalence }\end{array}$ & $\begin{array}{l}\text { Percentage of parents who self- } \\
\text { reported their a medical diagnosis } \\
\text { of diabetes in their child }\end{array}$ & $\begin{array}{l}6.50 \% \text { of obese youths with ID had diabetes compared } \\
\text { with } 1.4 \% \text { of youths with ID who are not obese }(P<0.05) \text {. } \\
\text { Diabetes rates were significantly higher in youths with ID } \\
\text { who were obese }(p<0.05)\end{array}$ & $>$ & $\begin{array}{l}\text { Case control } \\
\text { Over-representation of higher } \\
\text { education, higher } 5 \mathrm{ES} \text { and } \\
\text { Cacucasian participants } \\
\text { Use of self-report measures, no } \\
\text { distinction between level of ID, } \\
\text { type of diabetes and living } \\
\text { arrangements }\end{array}$ \\
\hline
\end{tabular}




\begin{tabular}{|c|c|c|c|c|c|c|c|}
\hline $\begin{array}{l}\text { Shireman et } \\
\text { al. (2010) } \\
\text { United } \\
\text { States of } \\
\text { America }\end{array}$ & $\begin{array}{l}\text { Sample size: } 6596 \\
\text { Gender: Females - } 50 \% \\
\quad \text { Males - } 50 \% \\
\text { Age: low - } 18 \text { high - } 65 \\
\text { mean - } 43 \\
\text { Mode ethnicity: Caucasian } \\
\text { Mode level of ID: none } \\
\text { identified } \\
\text { Mode diabetes type: none } \\
\text { identified } \\
\text { Mode genetic syndrome: } \\
\text { none identified } \\
\text { Mode comorbidity: none } \\
\text { identified } \\
\text { Mode Living arrangement: } \\
\text { None identified }\end{array}$ & $>$ & $\begin{array}{l}\text { Assessing the quality } \\
\text { of diabetes care for } \\
\text { adults with DD } \\
\text { Indirectly addressed } \\
\text { diabetes prevalence }\end{array}$ & $\begin{array}{l}\text { Percentage of participants with a } \\
\text { diagnosis of diabetes accessed } \\
\text { from health records }\end{array}$ & $11.20 \%$ of people with DD have diabetes & $\begin{array}{l}> \\
>\end{array}$ & $\begin{array}{l}\text { Cross-sectional } \\
\text { No issues identified } \\
\text { No distinction between level of } \\
\text { ID, type of diabetes and living } \\
\text { arrangements }\end{array}$ \\
\hline $\begin{array}{l}\text { Tyler et al } \\
2010 \\
\text { United } \\
\text { States of } \\
\text { America }\end{array}$ & 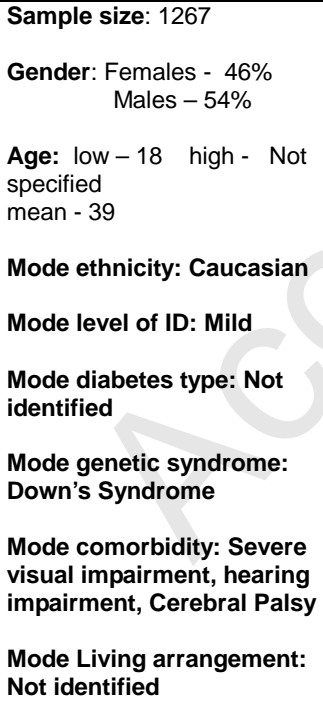 & & $\begin{array}{l}\text { An electronic health } \\
\text { records analysis of } \\
\text { adults with intellectual } \\
\text { and other } \\
\text { developmental } \\
\text { disabilities (IDD) } \\
\text { provided primary care } \\
\text { through a Cleveland, } \\
\text { Ohio, USA, area clinic } \\
\text { between } 2005 \text { and } \\
2008 . \\
\text { Indirectly addressed } \\
\text { diabetes prevalence }\end{array}$ & $\begin{array}{l}\text { Percentage of participants with a } \\
\text { diagnosis of diabetes accessed } \\
\text { from health records }\end{array}$ & $\begin{array}{l}\text { 10.3\% of adults with IDD had diabetes compared with } \\
15.2 \% \text { of matched non IDD controls. } \\
\text { Adults with IDD were significantly less likely to carry a } \\
\text { diagnosis of diabetes }(p<0.001) \text { than in matched controls } \\
\text { from the general population. }\end{array}$ & & $\begin{array}{l}\text { Case control } \\
\text { No issues identified } \\
\text { No distinction between } \\
\text { diabetes type or living } \\
\text { arrangement }\end{array}$ \\
\hline
\end{tabular}




\begin{tabular}{|c|c|c|c|c|c|c|c|}
\hline $\begin{array}{l}\text { Sohler et al } \\
2009 \\
\\
\text { United } \\
\text { States of } \\
\text { America }\end{array}$ & $\begin{array}{l}\begin{array}{l}\text { Sample size: } 291 \\
\text { Gender: Females - } 47.4 \% \\
\quad \text { Males - } 52.5 \%\end{array} \\
\begin{array}{l}\text { Age: unknown, } 55 \% \text { were < } \\
30\end{array} \\
\text { Mode ethnicity: Black } \\
\text { Mode level of ID: mild or } \\
\text { moderate } \\
\text { Mode diabetes type: not } \\
\text { identified } \\
\text { Mode genetic syndrome: } \\
\text { not identified } \\
\text { Mode comorbidity: } \\
\text { psychiatric illness, } \\
\text { hypertension, } \\
\text { hypercholesterolemia } \\
\text { Mode Living arrangement: } \\
\text { community }\end{array}$ & $>$ & $\begin{array}{l}\text { Sociodemographic and } \\
\text { clinical factors } \\
\text { associated with } \\
\text { obesity, hypertension, } \\
\text { hypercholesterolemia } \\
\text { and diabetes mellitus } \\
\text { in an ethnically / } \\
\text { racially diverse sample } \\
\text { of people with ID and } \\
\text { New York } \\
\text { Indirectly addressed } \\
\text { diabetes prevalence }\end{array}$ & How prevalence measured? & $\begin{array}{l}4.5 \% \text { of people with ID had diabetes. } \\
\text { Age, gender and BMI were the most consistent risk factors }\end{array}$ & $\overrightarrow{>}$ & $\begin{array}{l}\text { Case control } \\
\text { No issues identified } \\
\text { Age of people with ID not } \\
\text { specifically reported, No } \\
\text { distinction between diabetes } \\
\text { type }\end{array}$ \\
\hline $\begin{array}{l}\text { Straetmans } \\
\text { et al. (2007) } \\
\text { The } \\
\text { Netherlands }\end{array}$ & $\begin{array}{l}\text { Sample size: } 868 \\
\text { Gender: Females - unknown } \\
\quad \text { Males - unknown } \\
\text { Age: low - not identified } \\
\text { high - not identified, mean - } \\
\text { not identified } \\
\text { Mode ethnicity: none } \\
\text { identified } \\
\text { Mode level of ID: none } \\
\text { identified } \\
\text { Mode diabetes type: none } \\
\text { identified } \\
\text { Mode genetic syndrome: } \\
\text { none identified } \\
\text { Mode comorbidity: none } \\
\text { identified } \\
\text { Mode Living arrangement: } \\
\text { none identified }\end{array}$ & & $\begin{array}{l}\text { Exploring health } \\
\text { problems experienced } \\
\text { by people with ID } \\
\text { compared with the } \\
\text { general population } \\
\\
\text { Indirectly addressed } \\
\text { diabetes prevalence }\end{array}$ & $\begin{array}{l}\text { Percentage of participants with a } \\
\text { diagnosis of diabetes accessed } \\
\text { from health records }\end{array}$ & $\begin{array}{l}11.20 \% \text { of people with ID have diabetes compared to } \\
6.15 \% \text { of people in the general population who have } \\
\text { diabetes }(P<0.001)\end{array}$ & i & $\begin{array}{l}\text { Cross-sectional } \\
\text { No issues identified } \\
\text { No demographic data }\end{array}$ \\
\hline
\end{tabular}




\begin{tabular}{|c|c|c|c|c|c|c|c|}
\hline $\begin{array}{l}\text { McDermott } \\
\text { et al } 2007 \\
\text { United } \\
\text { States of } \\
\text { America }\end{array}$ & $\begin{array}{l}\text { Sample size: Cerbral Palsy } \\
\text { and mental retardation group } \\
\text { (CP\&MR)- 149, mental } \\
\text { retardation group (MR) - 291, } \\
\text { mental retardation and } \\
\text { psychiatric illness group } \\
\text { (MR\&PI) - } 145 \\
\text { Total with MR = } 585 \\
\text { Gender: Females - CP\&MR } \\
-54.4 \%, \text { MR - 44\%, MR\&PI } \\
-53.8 \% \text { Males - CP\&MR } \\
\text { - 45.6\%, MR - 56\%, MR\&PI } \\
-46.2 \% \\
\text { Age: low - not identified } \\
\text { high - not identified } \\
\text { Mean - 38 } \\
\text { Mode ethnicity: Only } \\
\text { reported for wider sample, } \\
\text { not specifically for MR } \\
\text { sample } \\
\text { Mode level of ID: Mild } \\
\text { Mode diabetes type: Not } \\
\text { identified } \\
\text { Mode genetic syndrome: } \\
\text { Not identified } \\
\text { Mode comorbidity: } \\
\text { Psychiatric illness, autism, } \\
\text { cerebral palsy, obesity } \\
\text { Mode Living arrangement: } \\
\text { Not identified }\end{array}$ & $>$ & $\begin{array}{l}\text { This research was } \\
\text { designed to answer the } \\
\text { question: Does the } \\
\text { prevalence of diabetes } \\
\text { differ between adults } \\
\text { with and without } \\
\text { disability, in the same } \\
\text { family medicine } \\
\text { practice. } \\
\text { Directly addressed } \\
\text { diabetes prevalence }\end{array}$ & $\begin{array}{l}\text { Percentage of participants with a } \\
\text { diagnosis of diabetes accessed } \\
\text { from health records. In addition, a } \\
\text { sample of patients also consented } \\
\text { to participate in an interview to } \\
\text { validate onset dates for conditions } \\
\text { and report on limitations in daily life. }\end{array}$ & $\begin{array}{l}\text { Overall } 9.8 \% \text { of people with a developmental disability } \\
\text { (combining CP\&MR, MR and MR \& PI had diabetes). } 6 \% \\
\text { of people with cerebral palsy and mental retardation, } \\
12.7 \% \text { of people with mental retardation and } 10.3 \% \text { of } \\
\text { people with mental retardation and a psychiatric illness } \\
\text { had diabetes compared to } 14.5 \% \text { of members of the } \\
\text { general population. } \\
\text { Diabetes revalence figures for people with developmental } \\
\text { disabilities overall rose to } 19.5 \% \text { of people with obesity } \\
\text { and fell to } 6.52 \% \text { for those who were not obese. } \\
\text { Less than general population but not statistically significant }\end{array}$ & & $\begin{array}{l}\text { Case control } \\
\text { No issues identified } \\
\text { No distinction made between } \\
\text { diabetes type and living } \\
\text { arrangement }\end{array}$ \\
\hline $\begin{array}{l}\text { McDermott } \\
\text { et al. (2006) } \\
\text { United } \\
\text { States of } \\
\text { America }\end{array}$ & $\begin{array}{l}\text { Sample size: } 669 \\
\begin{array}{l}\text { Gender: Females - } 37.3 \% \\
\text { Males - } 62.7 \%\end{array} \\
\text { Age: n/a longitudinal study } \\
\text { Mode ethnicity: none } \\
\text { identified } \\
\text { Mode level of ID: none } \\
\text { identified } \\
\text { Mode diabetes type: none } \\
\text { identified } \\
\text { Mode genetic syndrome: } \\
\text { none identified } \\
\text { Mode comorbidity: Cerebral } \\
\text { Palsy, Autism }\end{array}$ & $>$ & $\begin{array}{l}\text { Compared the health } \\
\text { status of adults with } \\
\text { DD, sensory } \\
\text { impairments, trauma- } \\
\text { related impairments } \\
\text { and psychiatric issues } \\
\text { against matched } \\
\text { controls without } \\
\text { impairments } \\
\text { Indirectly addressed } \\
\text { diabetes prevalence }\end{array}$ & $\begin{array}{l}\text { Percentage of participants with a } \\
\text { diagnosis of diabetes accessed } \\
\text { from health records }\end{array}$ & $\begin{array}{l}10.40 \% \text { of people with DD had diabetes compared to } \\
15.8 \% \text { in age matched non-disabled controls. }\end{array}$ & $\begin{array}{l}> \\
\bar{\nu}\end{array}$ & $\begin{array}{l}\text { Cross-sectional } \\
\text { No issues identified } \\
\text { No distinction between level ofl } \\
\text { ID, type of diabetes and living } \\
\text { arrangements }\end{array}$ \\
\hline
\end{tabular}




\begin{tabular}{|c|c|c|c|c|c|c|}
\hline & $\begin{array}{l}\text { Mode Living arrangement: } \\
\text { None identified }\end{array}$ & & & & & \\
\hline $\begin{array}{l}\text { Shah et al. } \\
\text { (2006) } \\
\text { United } \\
\text { Kingdom } \\
\text { (England) }\end{array}$ & $\begin{array}{l}\text { Sample size: } 119 \\
\text { Gender: Females - not } \\
\text { reported specifically for } \\
\text { people with ID } \\
\text { Males - not } \\
\text { reported specifically for } \\
\text { people with ID } \\
\text { Age: not reported } \\
\text { specifically for people with ID } \\
\text { Mode ethnicity: none } \\
\text { identified } \\
\text { Mode level of ID: none } \\
\text { identified } \\
\text { Mode diabetes type: none } \\
\text { identified } \\
\text { Mode genetic syndrome: } \\
\text { none identified } \\
\text { Mode comorbidity: None } \\
\text { identified } \\
\text { Mode Living arrangement: } \\
\text { Residential care / Nursing } \\
\text { homes }\end{array}$ & & $\begin{array}{l}\text { To assess the } \\
\text { prevalence of diabetes } \\
\text { among care home } \\
\text { residents and to gain } \\
\text { information on care } \\
\text { provided } \\
\text { Directly addressed } \\
\text { diabetes prevalence }\end{array}$ & $\begin{array}{l}\text { Percentage of participants listed as } \\
\text { having diabetes by Care Home } \\
\text { manager. Diabetes knowledge } \\
\text { gleaned from residents themselves, } \\
\text { their medical records or from their } \\
\text { GP or practice nurse. }\end{array}$ & $\begin{array}{l}5.9 \% \text { of people living in intellectual disability (ID) care } \\
\text { homes had diabetes }\end{array}$ & $\begin{array}{l}\text { Case control } \\
\text { Postal survey } \\
\text { No information on age, gender, } \\
\text { or ethnicity of people with ID. } \\
\text { No distinction made between } \\
\text { diabetes type of or level of ID. }\end{array}$ \\
\hline $\begin{array}{l}\text { Goldacre et } \\
\text { al. (2004) } \\
\text { United } \\
\text { States of } \\
\text { America }\end{array}$ & $\begin{array}{l}\text { Sample size: } 1453 \\
\text { Gender: Females - unknown } \\
\quad \text { Males - unknown } \\
\text { Age: n/a longitudinal study } \\
\text { Mode ethnicity: none } \\
\text { identified } \\
\text { Mode level of ID: none } \\
\text { identified } \\
\text { Mode diabetes type: none } \\
\text { identified } \\
\text { Mode genetic syndrome: } \\
\text { Down's Syndrome }\end{array}$ & & $\begin{array}{l}\text { Exploring the } \\
\text { prevalence of cancers } \\
\text { and immune-related } \\
\text { diseases in people with } \\
\text { Down's Syndrome } \\
\\
\text { Directly addressed } \\
\text { diabetes prevalence }\end{array}$ & $\begin{array}{l}\text { Percentage of participants with a } \\
\text { diagnosis of diabetes accessed } \\
\text { from health records }\end{array}$ & $\begin{array}{l}0.40 \% \text { of people with Down's Syndrome have diabetes } \\
\text { compared to } 0.1 \% \text { of people in the general population with } \\
\text { diabetes }(p<0.05) \\
\text { This risk increases in people with Down's syndrome under } \\
\text { the age of } 30(p<0.05)\end{array}$ & $\begin{array}{l}\text { Case control } \\
\text { No issues identified } \\
\text { No distinction between gender, } \\
\text { level of ID, type of diabetes } \\
\text { and living arrangements }\end{array}$ \\
\hline
\end{tabular}




\begin{tabular}{|c|c|c|c|c|c|c|}
\hline & $\begin{array}{l}\text { Mode comorbidity: None } \\
\text { identified } \\
\text { Mode Living arrangement: } \\
\text { None identified }\end{array}$ & & & 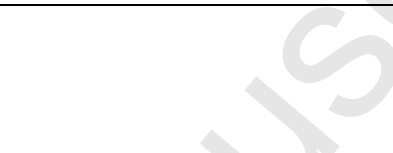 & & \\
\hline $\begin{array}{l}\text { Havercamp } \\
\text { et al. (2004) } \\
\text { United } \\
\text { States of } \\
\text { America }\end{array}$ & $\begin{array}{l}\text { Sample size: } 946 \\
\text { Gender: Females - } 43.9 \% \\
\quad \text { Males - } 56.1 \% \\
\text { Age: low - } 18 \text { high - not } \\
\text { identified, } 54+ \\
\text { Mean - not identified } \\
\text { Mode ethnicity: none } \\
\text { identified } \\
\text { Mode level of ID: mild } \\
\text { Mode diabetes type: none } \\
\text { identified } \\
\text { Mode genetic syndrome: } \\
\text { none identified } \\
\text { Mode comorbidity: none } \\
\text { identified } \\
\text { Mode Living arrangement: }\end{array}$ & $>$ & $\begin{array}{l}\text { Comparing the health } \\
\text { disparities between } \\
\text { adults with DD and } \\
\text { people without DD } \\
\text { Indirectly addressed } \\
\text { diabetes prevalence }\end{array}$ & $\begin{array}{l}\text { Percentage of participants with a } \\
\text { diagnosis of diabetes accessed } \\
\text { from health records }\end{array}$ & $\begin{array}{l}7.90 \% \text { of people with DD have diabetes compared to } 3.9 \% \\
\text { of people in the general population who have diabetes } \\
(p<0.05)\end{array}$ & $\begin{array}{l}\text { Cross-sectional } \\
\text { No issues identified } \\
\text { No distinction between level of } \\
\text { DD, type of diabetes and living } \\
\text { arrangements }\end{array}$ \\
\hline $\begin{array}{l}\text { Hoybe (2004) } \\
\text { Sweden }\end{array}$ & 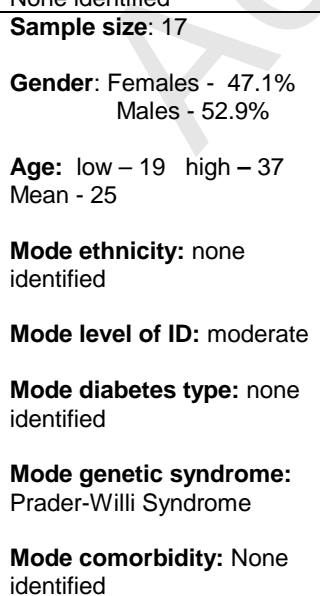 & & $\begin{array}{l}\text { Exploring endocrine } \\
\text { function in people with } \\
\text { Prader-Willi Syndrome } \\
\text { Indirectly addressed } \\
\text { diabetes prevalence }\end{array}$ & $\begin{array}{l}\text { Diabetes defined as a glucose level } \\
>11.1 \mathrm{mmol} / \mathrm{L} \\
\text { Prevalence calculated by } \\
\text { percentage of participants meeting } \\
\text { the above criteria }\end{array}$ & $5.90 \%$ of people with Prader-Willi Syndrome have diabetes & $\begin{array}{l}\text { Case control } \\
\text { No issues identified } \\
\quad \text { No distinction between level of } \\
\text { ID and type of diabetes }\end{array}$ \\
\hline
\end{tabular}




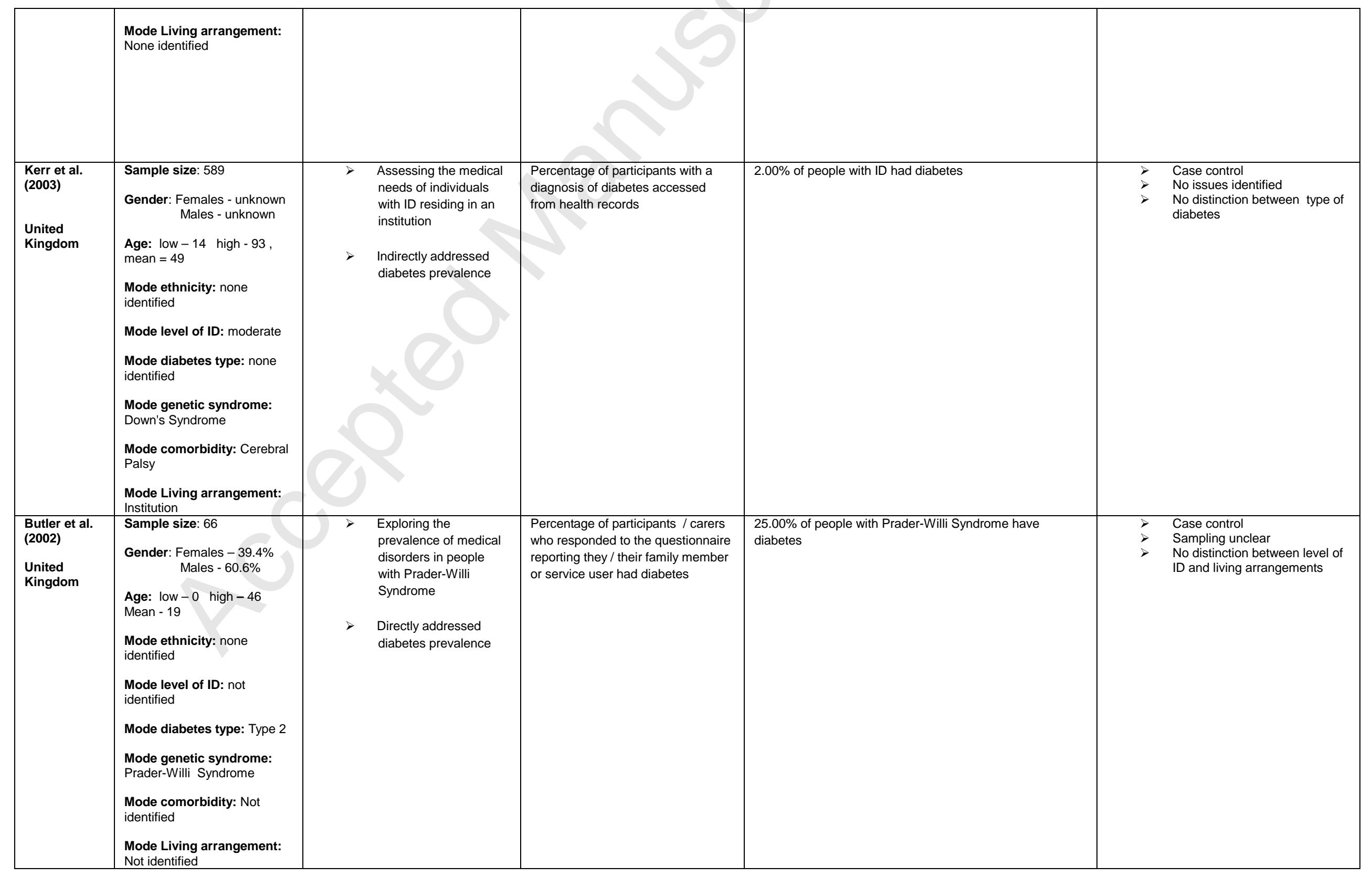




\begin{tabular}{|c|c|c|c|c|c|c|}
\hline $\begin{array}{l}\text { Van } \\
\text { Schrojenstei } \\
\text { n Lantman- } \\
\text { de Valk et al, } \\
1997 \\
\text { The } \\
\text { Netherlands }\end{array}$ & $\begin{array}{l}\text { Sample size: } 1020 \\
\text { Gender: Females - } 39.4 \% \\
\text { Males - } 60.6 \% \\
\text { Age: low - } 0 \text {, high - Not } \\
\text { identified, only } 70+ \\
\text { mean - not identified } \\
\text { Mode ethnicity: none } \\
\text { identified } \\
\text { Mode level of ID: not } \\
\text { identified } \\
\text { Mode diabetes type: not } \\
\text { identified } \\
\text { Mode genetic syndrome: } \\
\text { not identified } \\
\text { Mode comorbidity: Not } \\
\text { identified } \\
\text { Mode Living arrangement: } \\
\text { Institution }\end{array}$ & & $\begin{array}{l}\text { To determine the } \\
\text { prevalence and } \\
\text { incidence of the most } \\
\text { frequent chronic health } \\
\text { problems in relation to } \\
\text { age in people with ID } \\
\text { living in residential } \\
\text { facilities. } \\
\\
\text { Indirectly addressed } \\
\text { diabetes prevalence }\end{array}$ & $\begin{array}{l}\text { Percentage of participants / care } \\
\text { staff who had diabetes as assessed } \\
\text { by their medical records }\end{array}$ & $3.4 \%$ of people with ID had diabetes & $\begin{array}{ll}> & \text { Case control } \\
\text { Sampling unclear } \\
\text { Not all participants completed } \\
\text { all assessments }\end{array}$ \\
\hline
\end{tabular}


Table 4: Summary of studies of the views of people with intellectual disabilities and diabetes

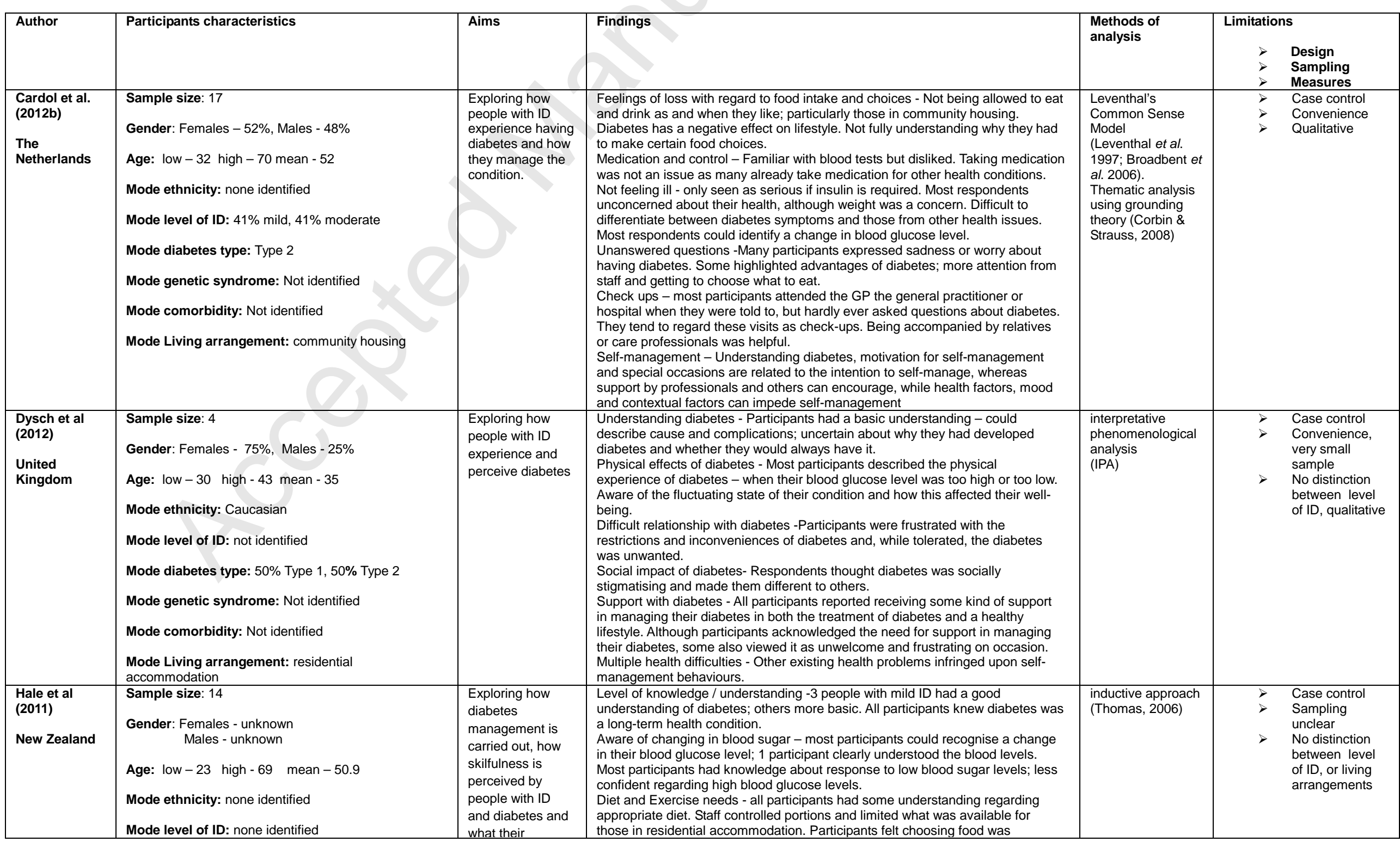




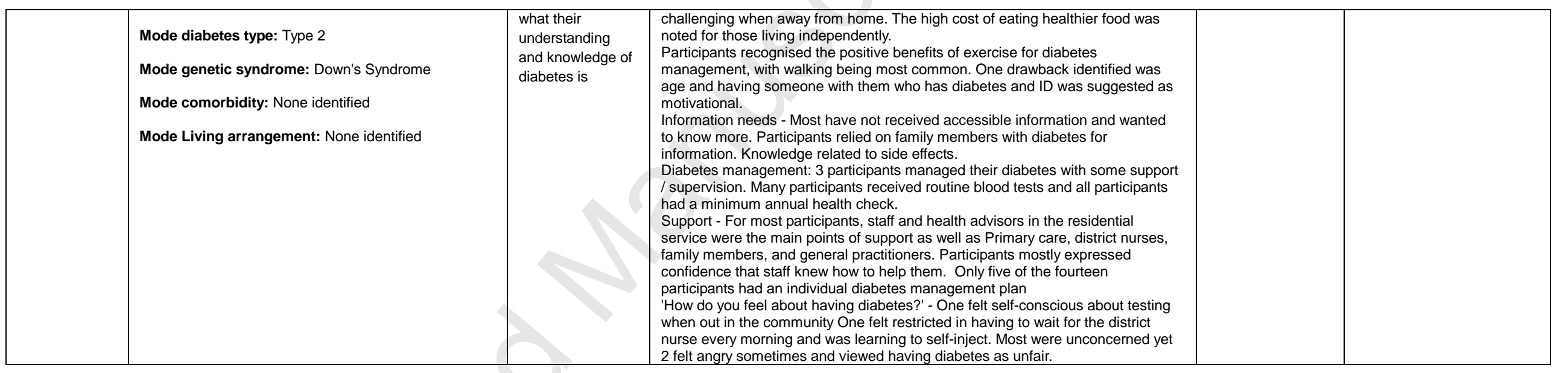


Table 5: Summary of studies of professionals and family carer views and experiences of intellectual disability and diabetes

\begin{tabular}{|c|c|c|c|c|c|}
\hline Author & $\begin{array}{l}\text { Participants } \\
\text { characteristics }\end{array}$ & Aims & Findings & $\begin{array}{l}\text { Methods of } \\
\text { analysis }\end{array}$ & $\begin{array}{l}\text { Limitations } \\
\begin{array}{ll}> & \text { Design } \\
> & \text { Sampling } \\
> & \text { Measures }\end{array}\end{array}$ \\
\hline $\begin{array}{l}\text { Hillege et } \\
\text { al (2013) } \\
\text { Australia }\end{array}$ & $\begin{array}{l}\text { Sample size: } 4 \\
\text { Gender: Females } \\
-50 \% \\
\text { Males - } 50 \% \\
\text { Age: not } \\
\text { identified } \\
\text { Mode ethnicity: } \\
\text { none identified } \\
\text { Mode work } \\
\text { setting: } \mathrm{n} / \mathrm{a} \text { family } \\
\text { carers }\end{array}$ & $\begin{array}{l}\text { Exploring the } \\
\text { challenges for } \\
\text { families managing an } \\
\text { adolescent with an ID } \\
\text { and T1D }\end{array}$ & $\begin{array}{l}\text { Independence and ID - Parents views relate to double disadvantaged due to diabetes and ID, lacked independence } \\
\text { that would be life-long. All parents thought their sons would never live independently due to support in activities of daily } \\
\text { living and diabetes management. } \\
\text { Independence and diabetes management - One mother of the view that family member would be more independent if } \\
\text { ID only without diabetes Parents reported physical and mental impairments make diabetes self-management difficult, } \\
\text { such as limited dexterity to test blood glucose level, the ability to self-inject nor the numerical skills to calculate the } \\
\text { correct dosage. Parents of the view that users had basic understanding of routine and equipment requirements for } \\
\text { blood tests and insulin injections; limited comprehension of implications. All parents' views about enabling self-manage } \\
\text { of diabetes through promoting learning and independence versus potential risks. } \\
\text { Independence and responsibility - necessity for others, both inside and outside the home, to be involved in their sons' } \\
\text { diabetes care but that they, the parents, always bear at least part of the responsibility for this and have had to educate } \\
\text { various carers and teachers over the years. Diabetes placed restrictions on family life and limited spontaneity due to } \\
\text { planning care. All parents resilient in responding to issues related to family member's diabetes. }\end{array}$ & $\begin{array}{l}\text { Case study } \\
\text { analysis } \\
\text { Manifest and } \\
\text { latent content } \\
\text { (Berg, 2007) }\end{array}$ & $\begin{array}{l}\text { Case control } \\
\text { Convenience, very } \\
\text { small sample } \\
\text { No demographic } \\
\text { data, qualitative }\end{array}$ \\
\hline $\begin{array}{l}\text { Cardol et } \\
\text { al (2012a) } \\
\text { The } \\
\text { Netherland } \\
\text { s }\end{array}$ & $\begin{array}{l}\text { Sample size: } 13 \\
\text { Gender: Females } \\
-84.6 \% \\
\text { Males - } 15,4 \% \\
\text { Age: not } \\
\text { identified } \\
\text { Mode ethnicity: } \\
\text { none identified } \\
\text { Mode job role: } \\
\text { social worker } \\
\text { Mode work } \\
\text { setting: Small } \\
\text { community } \\
\text { houses }\end{array}$ & $\begin{array}{l}\text { Exploring how } \\
\text { professional care } \\
\text { givers in communal } \\
\text { living arrangements } \\
\text { support people with } \\
\text { ID and diabetes }\end{array}$ & $\begin{array}{l}\text { Perceived severity of diabetes - most caregivers did not view diabetes as a serious condition unless insulin was } \\
\text { required or might lose consciousness. } \\
\text { Perceptions regarding the motivation and capabilities of the person with diabetes - respondents stated that they did not } \\
\text { always trust the client as they might eat in secret and steal food. Nine caregivers were negative about the capability of } \\
\text { the person with intellectual disability and diabetes to learn and self-manage diabetes to some extent. } \\
\text { Knowledge and educational needs of the caregivers - nurses were found to have more knowledge than social workers } \\
\text { and most social workers underwent additional training to learn about diabetes, which covered insulin administration but } \\
\text { not how to support someone to self-manage. Some respondents wanted more diabetes knowledge whereas others } \\
\text { relied on the knowledge of specialist medical staff. } \\
\text { Self-management support - all caregivers cited medical management and controlling food intake as special care or } \\
\text { support they provide in relation to diabetes. Some mentioned support in teaching how to deal with dietary rules. Some } \\
\text { participants stated that it was not always clear who bears responsibility for diabetes management and most said they } \\
\text { provided support that was more directed towards control and prohibition, and that informing and engaging in self- } \\
\text { management was rare. Caregivers who had positive attitudes towards the learning ability of their clients highlighted } \\
\text { trust, a positive approach, creative solutions and flexibility as key components of their support. Personal goal setting, } \\
\text { appointments and structure were found to be additional important aspects of support. Contextual factors, such as } \\
\text { consistency within the team and collaboration with health care professionals and family members were identified as } \\
\text { important, whereas a lack of diabetes education material, other residents in the community housing that need a lot of } \\
\text { attention, and inadequate equipment were identified as impediments to support and self-management. } \\
\text { Balancing health management and quality of life - all participants experienced a dilemma in wanting their support to be } \\
\text { person-centered yet also wanting to provide good diabetes care. }\end{array}$ & $\begin{array}{l}\text { Thematic } \\
\text { analysis using } \\
\text { strategies } \\
\text { from grounded } \\
\text { theory }\end{array}$ & $\begin{array}{ll}\text { Case control } \\
\text { Convenience, } \\
\text { over- } \\
\text { representation of } \\
\text { female social } \\
\text { workers } \\
\text { No demographic } \\
\text { data aside from } \\
\text { gender, qualitative }\end{array}$ \\
\hline $\begin{array}{l}\text { Hale et al } \\
\text { (2011) }\end{array}$ & $\begin{array}{l}\text { Sample size: } 14 \\
\text { Gender: Not } \\
\text { identified } \\
\text { Age: Not } \\
\text { identified } \\
\text { Mode ethnicity: } \\
\text { none identified } \\
\text { Mode work } \\
\text { setting: none } \\
\text { identified }\end{array}$ & $\begin{array}{l}\text { Exploring how } \\
\text { diabetes } \\
\text { management is } \\
\text { carried out, how } \\
\text { skilfulness is } \\
\text { perceived by people } \\
\text { with ID and diabetes } \\
\text { and what their } \\
\text { understanding and } \\
\text { knowledge of } \\
\text { diabetes is }\end{array}$ & $\begin{array}{l}\text { Two of the participants were unaware that the person they support had an individualised diabetes management plan } \\
\text { despite this being readily available, } 1 \text { stated that staff need to check that the individual they support read his blood } \\
\text { sugar levels correctly, remind him to wash his hands and ensure an appropriate diet, and another member of staff } \\
\text { raised concern about troubles with numeracy for a client which affected self-management abilities. }\end{array}$ & $\begin{array}{l}\text { Inductive } \\
\text { approach } \\
\text { (Thomas, } \\
\text { 2006) }\end{array}$ & $\begin{array}{ll}\text { Case control } \\
\text { Sampling unclear } \\
\text { Only } 4 \text { out of } 14 \\
\text { staff participants } \\
\text { are reported on, } \\
\text { no demographic } \\
\text { data, qualitative }\end{array}$ \\
\hline
\end{tabular}




\section{Highlights}

- Previous research suggests significantly higher rates of diabetes in people with ID than the general population.

- People with ID report a basic understanding of diabetes and want to know more

- Existing mainstream diabetes management programmes need to be modified or developed for people with intellectual disabilities

- Carers report that they lack diabetes knowledge and do not routinely encourage diabetes self-management skills 